\title{
Advances in Proteasome Enhancement by Small Molecules
}

\author{
Dare E. George $(\mathbb{D})$ and Jetze J. Tepe * \\ Department of Chemistry and Pharmacology \& Toxicology, Michigan State University, \\ East Lansing, MI 48824, USA; georg186@msu.edu \\ * Correspondence: tepe@chemistry.msu.edu
}

check for

updates

Citation: George, D.E.; Tepe, J.J.

Advances in Proteasome

Enhancement by Small Molecules.

Biomolecules 2021, 11, 1789. https://

doi.org/10.3390/biom11121789

Academic Editor: Shigeo Murata

Received: 27 October 2021

Accepted: 26 November 2021

Published: 30 November 2021

Publisher's Note: MDPI stays neutral with regard to jurisdictional claims in published maps and institutional affiliations.

Copyright: (c) 2021 by the authors. Licensee MDPI, Basel, Switzerland. This article is an open access article distributed under the terms and conditions of the Creative Commons Attribution (CC BY) license (https:/ / creativecommons.org/licenses/by/ $4.0 /)$.

\begin{abstract}
The proteasome system is a large and complex molecular machinery responsible for the degradation of misfolded, damaged, and redundant cellular proteins. When proteasome function is impaired, unwanted proteins accumulate, which can lead to several diseases including age-related and neurodegenerative diseases. Enhancing proteasome-mediated substrate degradation with small molecules may therefore be a valuable strategy for the treatment of various neurodegenerative diseases such as Parkinson's, Alzheimer's, and Huntington's diseases. In this review, we discuss the structure of proteasome and how proteasome's proteolytic activity is associated with aging and various neurodegenerative diseases. We also summarize various classes of compounds that are capable of enhancing, directly or indirectly, proteasome-mediated protein degradation.
\end{abstract}

Keywords: proteasome; neurodegeneration; cancer; ubiquitin; 20S; 26S; misfolded; disordered; degradation; protein

\section{Introduction}

The degradation of proteins is a continual process that is highly regulated by the two major proteolysis systems, the lysosomal degradation pathway and the proteasomemediated pathway. Protein degradation helps maintain biological homeostasis in cells which are needed for all cell functions and for maintaining optimal conditions for enzyme function [1]. The proteasome pathway is the major pathway for the degradation of misfolded, oxidatively damaged, and redundant proteins. Dysregulation of proteasome function has been identified in the pathogenesis of several neurodegenerative diseases including Parkinson's disease (PD) [2], Alzheimer's disease (AD), and other neurodegenerative diseases [3]. The proteasome pathway is also involved in the regulation of several other cellular processes such as cell cycle, stress signaling, gene expression regulation, inflammatory response, cell differentiation, and apoptosis, which makes it an appealing target in the treatment of other types of diseases, including cancer [4]. Due to the critical role of the proteasome-mediated degradation pathway in cell regulation, the modulation of proteasome proteolytic activity has become a valuable strategy in the pursuit of new therapeutics to treat several neurodegenerative diseases [5-8].

\subsection{The Human Proteasome}

The human proteasome is a large complex protein responsible for the intracellular degradation of unwanted and damaged proteins via a ubiquitin-dependent and ubiquitinindependent degradation pathway. The most common proteolytic clearance of proteins proceeds by tagging the protein with polyubiquitin, after which it is degraded into small peptides of seven to eight amino acids by the $26 \mathrm{~S}$ proteasome [9]. Highly disordered proteins can also be degraded in a ubiquitin-independent manner by the 20S proteasome [10]. In this review, we will cover the use of small molecules to enhance the proteolytic activity of both the $26 \mathrm{~S}$ proteasome and the $20 \mathrm{~S}$ proteasome. 


\subsection{Ubiquitin-Proteasome System}

\subsubsection{Ubiquitin}

Ubiquitin (Ub) is a small protein (approximately $8600 \mathrm{Da}$ ) with 76 amino acid residues responsible for tagging a wide range of cellular proteins for proteolytic degradation. In the ubiquitin-proteasome system (UPS) (Figure 1), proteins are tagged for proteolysis by covalent ligation to ubiquitin [11]. Ubiquitination of proteins requires three enzymes in chronological order (see Figure 1a). The E1 ubiquitin-activating enzyme, just like its name, activates the $\mathrm{C}$-terminal glycine residue of the ubiquitin in an ATP-dependent manner. The binding of the ubiquitin to a cysteine residue of E1 forms a Ub-E1 complex via a thioester linkage. The E2 ubiquitin-conjugating enzymes transfer the ubiquitin from the Ub-E1 complex to itself via a trans-thioesterification to form the Ub-E2 complex and release the E1 enzyme from the system. Lastly, the ubiquitin ligases E3s are responsible for selecting proteins for ubiquitin-mediated proteolysis. Humans have two E1 enzymes, about 40 E2 enzymes, and are estimated to have about 500-1000 E3s [12].

a) Protein Ubiquitination Pathway

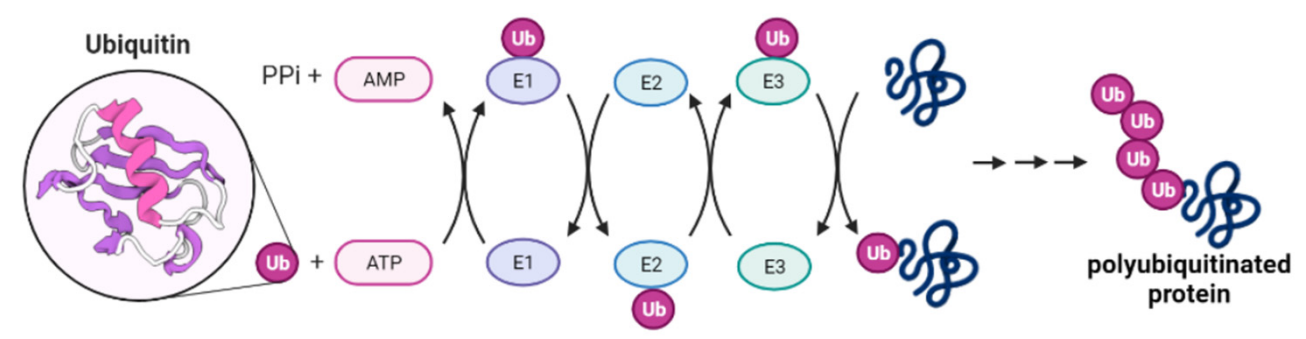

b) Polyubiquitinated Protein Degradation

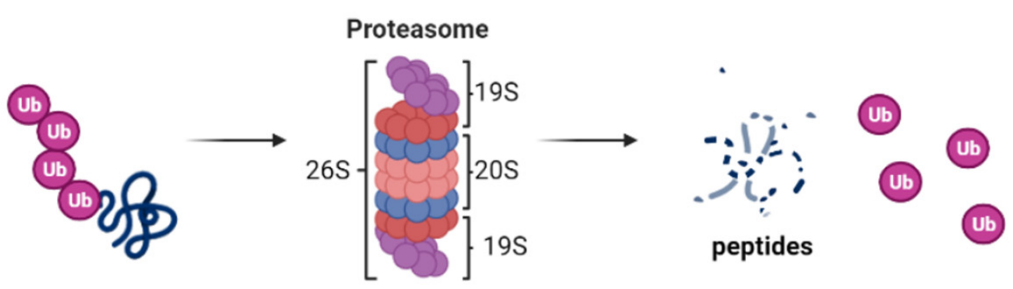

Figure 1. Ubiquitin-proteasome system [13]. (a) Protein polyubiquitination process using the ubiquitin-activating enzyme E1, conjugating enzymes E2 and the E3 ligase; (b) Polyubiquitinated proteins are degraded by $26 \mathrm{~S}$ proteasome into small peptides following its deubiquitination.

After monoubiquitination of the targeted protein, the C-terminus of each ubiquitin molecule can be linked to any of the other seven lysine residues (K6, K11, K27, K29, $\mathrm{K} 33, \mathrm{~K} 48$, and $\mathrm{K} 63$ ) on the previous ubiquitin to extend the ubiquitin chain and form the polyubiquitinated tagged protein $[14,15]$. However, the signal for protein degradation by the proteasome usually involves the linking of $\mathrm{Ub}$ to the $\mathrm{K} 48$ of the previous $\mathrm{Ub}$ on the protein [16,17]. In addition, K11, K29, and K63 linked chains have also been shown to play a role in proteasomal degradation $[17,18]$. The $26 S$ proteasome degrades polyubiquitinated proteins (see Figure $1 \mathrm{~b}$ ), and a previous study shows that proteins marked for degradation must be tagged with at least four ubiquitin molecules to be recognized by the 26S proteasome [16,19]. However, shorter chains, monoubiquitinated and multiple monoubiquitinated proteins can also be targeted for degradation by the proteasome [20-23]. It is also important to note that the ubiquitination process is reversible, and the deubiquitinating enzymes (see Section 3.1.1) are present in the cell to remove ubiquitin-tagged proteins [24]. 


\subsubsection{The 26S Proteasome}

The $26 \mathrm{~S}$ proteasome has a molecular weight of approximately $2.5 \mathrm{MDa}$ and it is made up of the $20 \mathrm{~S}$ core particle (CP), and one or two $19 \mathrm{~S}$ regulatory particle(s) (RP) attached to one or both end(s) of the CP [25]. The 19S RP (also known as PA700) binds to the 20S CP and facilitates the gate opening of the $\mathrm{CP}$ for proteolytic degradation of polyubiquitinated proteins [26]. The 19S RP is also responsible for recognizing, unfolding, and translocating polyubiquitinated protein into the 20S CP [27]. Cryo-EM studies have shown many conformation states of the $26 \mathrm{~S}$ proteasome when engaged with substrate [28-35]. Some of these studies showed the processes by which substrate is engaged, deubiquitylated, unfolded, and translocated by the proteasome [28,29]. The proteasome is also referred to as the $30 \mathrm{~S}$ proteasome when the 20S CP is capped at both ends with the 19S RP [36]. However, in this review, we will refer to the $26 \mathrm{~S}$ proteasome without distinguishing between the singly or doubly capped CP.

\subsection{The $20 \mathrm{~S}$ Proteasome or Core Particle}

The $20 \mathrm{~S}$ proteasome is a $700 \mathrm{kDa}$ protein with a cylindrical-like structure. The $\mathrm{CP}$ contains four heptameric rings stacked on each other in an $\alpha_{1-7} \beta_{1-7} \beta_{1-7} \alpha_{1-7}$ fashion. The outer $\alpha$-rings form a gate, and they recognize regulatory particles that allow the opening and closing of the gate [37]. The inner $\beta$-rings contains six proteolytic sites, three on each $\beta$-ring $(\beta 1, \beta 2$, and $\beta 5)$, and are responsible for the proteolytic activity of the proteasome.

The three different proteolytic sites of the $20 \mathrm{~S} \mathrm{CP}$ exhibit different substrate preferences even though they all use $\mathrm{N}$-terminal nucleophilic threonine to carry out their proteolytic activities. The $\beta 1$ exhibits a caspase-like (C-L)/PGPH (peptidylglutamyl-peptide hydrolyzing) activity and preferentially cleaves after acidic residues. The $\beta 2$ and $\beta 5$ exhibit trypsin-like (T-L) and chymotrypsin-like (CT-L) activities, and they preferentially cleave after basic and hydrophobic residues, respectively [38]. The 20S proteasome on its own degrades unstructured proteins using a ubiquitin-independent pathway.

\subsection{Small Molecule Regulation of Proteasome Function}

Due to the role of the proteasome in cellular functions, the regulation of proteasome has become a valuable target for the development of therapeutic molecules [39]. Proteasome inhibition is a therapeutic approach for the treatment of cancer. For example, bortezomib, a dipeptide boronate, was approved by the FDA in 2003 as an anticancer drug to treat mantle cell lymphoma and multiple myeloma [40,41]. Bortezomib inhibits the $26 \mathrm{~S}$ proteasome by forming a covalent bond between its boron atom and threonine oxygen in the CT-L catalytic site of the 20S CP [40]. Molecules that inhibit the proteasome have also been shown to induce apoptosis in cell cultures and murine models of cancer. One of the proposed mechanisms is that proteasome inhibition prevents the degradation of the $\mathrm{I} \kappa \mathrm{B}$, an NF- $\kappa$ B inhibitor, which prevents NF- $\kappa$ B nuclear translocation and consequently NF$\kappa \mathrm{B}$ mediated gene expression [42]. Proteasome inhibition results in the accumulation of I $\kappa$ B [43-48], cyclin-dependent kinase (CDK) inhibitor p21 [43,49,50], tumor suppressor p53, and other pro-apoptotic proteins [51-53]. The exceptional increase in apoptosis of certain multiple myeloma cells when treated with proteasome inhibitors has also been linked to an increase in protein unfolding and increasing substrate load on the proteasomes [54,55]. In addition, proteasome inhibition leads to lethal shortage of amino acids in the cells, which are the building blocks for cells to make new proteins. This amino acid scarcity caused by proteasome inhibition results in increasing ER stress and cell apoptosis [56]. Many reviews on proteasome inhibition have recently been published [57-66], including a recent review by our group on natural products scaffolds as inhibitors of the proteasome [67].

Proteasome activation by small molecules is a proposed strategy for the treatment of age-related diseases and several neurodegenerative diseases such as Parkinson's disease (PD), Alzheimer's Disease (AD), Huntington's Disease (HD), and Amyotrophic Lateral Sclerosis [8,68-72]. Increasing the proteolytic activity of proteasome enhances the degradation of specific intrinsically disordered proteins (IDPs) such as $\alpha$-synuclein, $\beta$-amyloid, 
and tau, to mention a few, which are associated with the pathogenesis of these neurodegenerative diseases. This review will focus on the use of small molecule enhancers of proteasome-mediated proteolysis as a potential strategy for the treatment of various neurodegenerative diseases.

\section{Proteasome Activity and Diseases}

As humans age, there is a decline in proteasome function [3,73]. This reduction could be due to the reduction in the expression of proteasome subunits [74], oxidative damage of the protein $[75,76]$, and disassembly of the $26 \mathrm{~S}$ proteasome holocomplex $[77,78]$. The decrease in proteasome proteolytic function leads to lower rates of unwanted protein degradation which can induce toxic signaling upon accumulation and aggregation (Figure 2). In particular, the accumulation of specific intrinsically disordered proteins (IDPs), such as amyloid- $\beta$ and $\alpha$-synuclein, have been identified as a driving cause of many neurodegenerative diseases [79-98]. The exact mechanism by which these oligomers induce neurotoxicity is complex and still debated, but it is widely accepted that dysregulated IDPs accumulate, and the resulting soluble oligomeric forms of these protein aggregates are likely toxic species in disease pathogenesis [79,93,99-102]. These soluble oligomeric forms are also responsible for impairing proteasome function, which further drives disease progression [94,103-120]. Multiple studies have indicated that enhancing proteasome proteolytic activity prevents the accumulation of these IDPs, reduces brain damage and improves cognitive performance in mouse models, and may be a new therapeutic strategy to treat neurodegenerative diseases [8,68-70,72,119,121-132]. More recently, it has been recognized that the $20 \mathrm{~S}$ proteasome of the proteasome plays a critical role in maintaining proteostasis by the direct degradation of oxidatively damaged and highly disordered proteins [10,133-138]. The 20S proteasome, therefore, serves as the default protease to unremittently maintain low levels of these unwanted IDPs without the need for posttranslation modifications, including protein ubiquitination [10,133]. Highly disordered proteins appear to be the main target of the 20S proteasome [139]. IDPs are also naturally short-lived, but basal levels are secured by forming proteolytically stable structured complexes with "nannies", chaperones, or other protein complexes [140]. However, when these IDPs production outpaces their degradation, they accumulate, oligomerize, and aggregate, resulting in the induction of downstream cytotoxic signaling events.

\subsection{Aging}

During aging, proteins are more susceptible to several types of modification, such as oxidation, glycoxidation, glycation, conjugation with peroxidation products, etc. These protein modifications can lead to decreased enzyme activity and thermodynamic stability [141,142], resulting in the accumulation of damaged proteins in the cell. Several models used to study proteasome proteolytic activity showed a decline in proteasomal activity as we age $[143,144]$ and decreased degradation of oxidized proteins in cell cultures $[145,146]$. Reactive oxygen species accumulate during aging, resulting in an increase of oxidatively damaged proteins and an increased demand on the proteasome degradation system to eliminate these pathogenic aggregation-prone proteins [113]. Unfortunately, proteasome proteolytic activity declines as we age $[3,73,75]$, resulting in the accumulation of oxidatively damaged proteins [147].

These unwanted protein aggregates interact with the proteasome and further reduce its proteolytic capacity [104-107,111,113]. This inhibition of proteasome leads to a compounding accumulation of more unwanted proteins and a vicious cycle of progressively worsening aggregation of oxidatively damaged proteins [94,104-107,116-119,148-150]. 


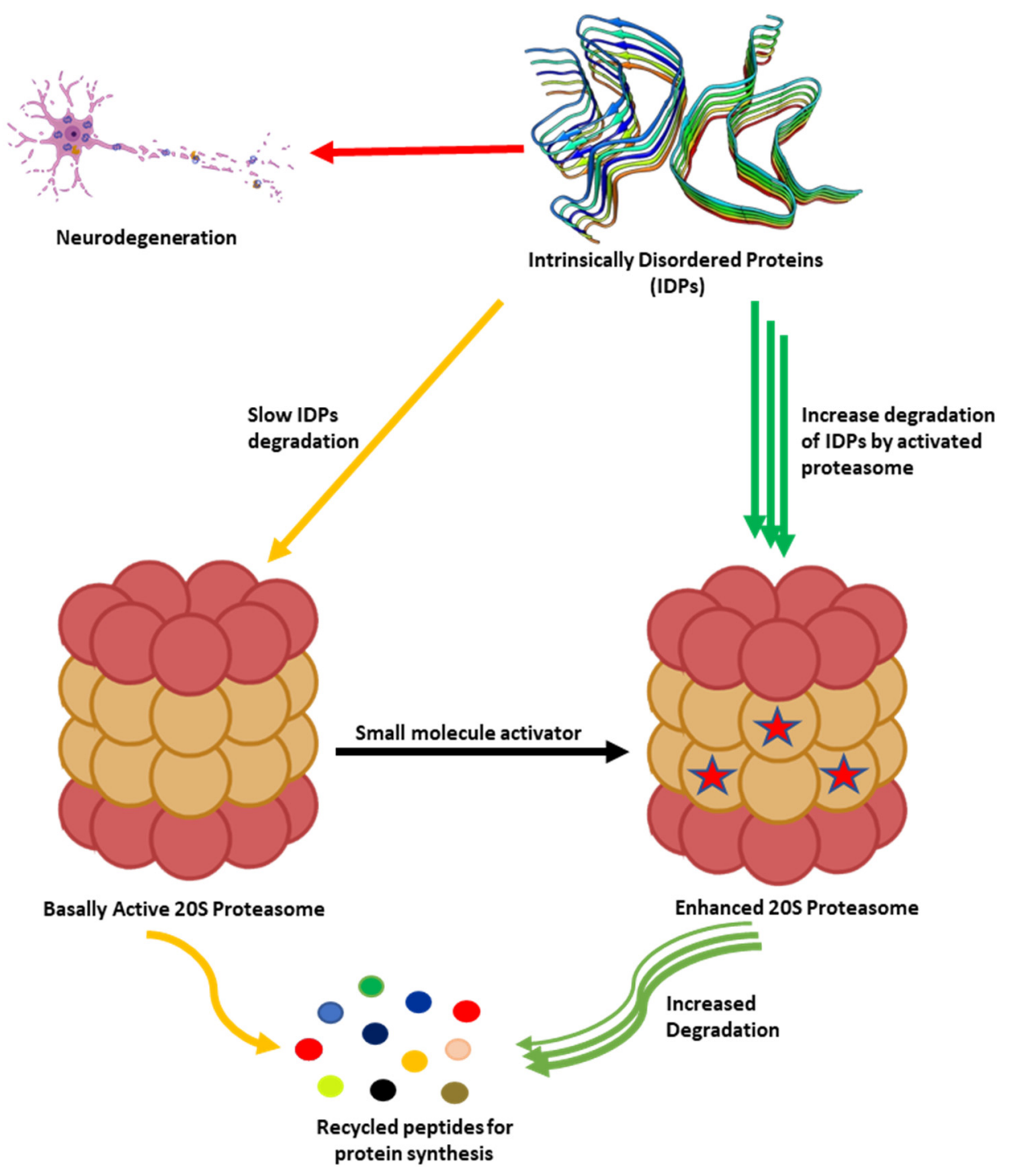

Figure 2. Accumulation of partially unfolded, misfolded, and dysregulated intrinsically disordered proteins (IDPs) such as amyloid- $\beta$ and $\alpha$-synuclein leads to neurotoxicity and neuronal cell death. The 205 proteasome degrades unwanted IDPs; however, small molecules can enhance the rate of proteasome-mediated degradation of these IDPs and prevent their accumulation.

\subsection{Neurodegenerative Diseases}

\subsubsection{Parkinson's Disease (PD)}

Approximately 10 million people worldwide are affected by PD, making it the second most prevalent neurodegenerative disorder [151]. PD is characterized pathologically by the loss of dopaminergic neurons as a result of the accumulation of Lewy bodies in the substantia nigra pars compacta (SNc) [152]. Lewy bodies are the defining pathological hallmark of PD, and its major components are $\alpha$-synuclein, ubiquitin, parkin, proteasomal components, and other UPS-related proteins. PD has been linked to various UPS proteins such as parkin and UCH-L1. Additionally, the expression of mutant $\alpha$-synuclein in rat cells inhibits proteasome proteolytic activity, causing essential features common to PD such as inclusion body formation, accumulation of undegraded ubiquitinated protein, and cell death. Dysregulation of proteasome-mediated protein degradation has been associated with both familial and sporadic PD [153].

Different approaches have been used to determine the role of the proteasome in the pathology of PD. Rat models have been developed to display characteristics such as bradykinesia, tremor, and abnormal posture, which are similar to PD when treated with 
proteasome regulators [154]. In addition, $\alpha$-synuclein and ubiquitin-containing inclusion resembling Lewy bodies were also present at the neurodegenerative sites of the rat neurons. However, other studies could not reproduce similar output [155], which became controversial and indicated that proteasome inhibition is not a reliable model to study PD. As an alternative approach to study the development of PD, mouse models of proteasome subunits knock-out were generated. However, the removal of most proteasome genes causes embryonic lethality except for a few immune-related subunits $[109,156]$. The deletion of the proteasomal ATPase subunit Psmc1/Rpt2 in the dopaminergic neurons leads to intraneuronal $\alpha$-synuclein and ubiquitin-positive inclusion, which resulted in neurodegeneration and thus resembling the human PD. This study provided direct support for the involvement of neuronal proteasome and Lewy-like inclusion seen in PD [157].

\subsubsection{Alzheimer's Disease (AD)}

$\mathrm{AD}$ is the most common cause of dementia, and it is ranked as the sixth leading cause of death in the United State as of 2019 [158]. AD is associated with loss of cognitive functioning such as memory, thinking, and reasoning. It also impacts behavioral activities such as the ability to carry out daily life activities [159].

The pathogenesis of $\mathrm{AD}$ has been attributed to protein misfolding and aggregation $[80-82,84,89]$. It is characterized by the aggregation of extracellular $\beta$-amyloid plaques and intracellular accumulation of neurofibrillary tangles [160]. The neurofibrillary tangles (NFTs) are mostly composed of hyperphosphorylated microtubule-associated tau. Filamentous tau formation is triggered due to changes in the concentration of $\beta$-amyloid [160]. Although $\beta$-amyloid appears to be more specific to $A D$, tau is also associated with other neurodegenerative diseases such as corticobasal degeneration, chronic traumatic encephalopathy, argyrophilic grain disease, and progressive supranuclear palsy [161].

Different experimental and clinical data have shown that the main drivers of synaptic dysfunction, cognitive decline, and neuronal loss in AD patients are associated with soluble toxic $\beta$-amyloid oligomers which impair proteasome proteolytic activity, rather than insoluble $\beta$-amyloid plaques [111,162-165].

The ubiquitin-dependent proteasome system is associated with $\mathrm{AD}$ and degradation of $\beta$-amyloid [120,166-168]. Studies showed that the activity of the proteasome decreases in some parts of the brain in AD patients [169]. Similarly, inhibition of the 26S proteasome by lactacystin resulted in the accumulation of $\beta$-amyloid in both astrocytes and neurons, suggesting that $\beta$-amyloid could be a substrate for proteasomal degradation [166]. These results indicate that enhancing proteasome proteolytic activity may alleviate some of the factors that drive the pathogenesis of AD.

\subsubsection{Huntington's Disease (HD)}

$\mathrm{HD}$ is a brain disorder caused by the mutations of the huntingtin $(\mathrm{Htt})$ gene. HD affects mood, movement and also leads to progressive cognitive deterioration and psychosis as a result of changes in the central part of the brain. The disease is dominant, which implies that it is inheritable by children from their parents.

In $\mathrm{HD}$ the disorder of polyglutamine in the Htt protein results in toxic functions of mutant $\mathrm{Htt}$, which consequently leads to neurodegeneration. The HD mutation is an unstable expansion of trinucleotide CAG repeats within the Htt gene, which causes polyglutamine stretch in the N-terminal of the protein and results in the formation of fibril and aggregates [170]. Remarkably, the mutant Htt still retains some of the functions of a normal Htt. The number of CAG repeats correlates to the progression of $\mathrm{HD}$ and the symptoms. Individuals with 36-40 CAG repeats may or may not develop HD symptoms. However, those with CAG repeats above 40 will eventually develop HD [171,172]. Greater than 50 long CAG repeats cause early onset of the disease (juvenile HD) [173]. Several studies suggest that mutant $\mathrm{Htt}$ aggregates impair the ubiquitin-proteasome system [104,116,174]. However, the actual mechanism of interaction between the mutant Htt aggregate and the proteasome remains unclear. Interestingly, unlike the soluble $\mathrm{Htt}$, the $\mathrm{Htt}$ aggregates have 
been found to be ubiquitinated, and those insoluble aggregates have also been shown not to impair the activity of the $26 \mathrm{~S}$ proteasome $[175,176]$. The inclusions associated with HD have been proposed to be toxic and lead to neuronal death. But the exact mechanism of toxicity remains unsolved. Increasing proteasome-mediated substrate degradation has been shown to increase survival in HD patients' mutant huntingtin-expressing striatal and skin fibroblasts neurons. Over expression of PA28 $\gamma$, a proteasome activator subunit also improved cell viability [177].

\subsubsection{Amyotrophic Lateral Sclerosis (ALS)}

ALS is another progressive neurodegenerative disease that affects the motoneurons in the brain and spinal cord. ALS is characterized by spasticity, muscle weakness, atrophy, and paralysis. The disease is often lethal within three to five years after diagnosis [178-180]. Like other neurodegenerative diseases, most ALS cases are sporadic (sALS), while about $10 \%$ could be familial (fALS) and result as a mutation in multiple genes [178]. Also, both sALS and fALS are clinically indistinguishable. Efforts at determining the mechanism underlying different fALS forms are thought to give insight into target identification and therapeutics development for both forms of diseases.

The first ALS-linked genetic mutation was found in 1993, and it was located in the gene coding of $\mathrm{Cu}-\mathrm{Zn}$ superoxide dismutase 1 (SOD1) [181]. Since then, several ALS mutant genes have been identified [178,182-184]. The recently discovered C9orf72 gene mutation has been identified as the most common cause of fALS and frontotemporal dementia $[185,186]$. An expansion of a GGGGCC repeat in the C9orf72 gene translates into five dipeptide-repeats proteins: poly-GA, poly-GP, poly-GR, poly-PR, and poly-PA [187-191]. A study showed that poly-GA aggregates recruit numerous $26 \mathrm{~S}$ proteasome complexes which may affect neuronal proteasome-mediated proteostasis and the protein degradation process [192].

Both the sALS and fALS are often considered proteinopathies since they both tend to aggregate and accumulate misfolded and abnormal proteins generated in the damaged neurons $[193,194]$. The presence of ubiquitinated rich protein inclusions in motor neurons is a feature considered a common hallmark of not only human ALS but also in cellular and animal models of the disease $[195,196]$. The abundant accumulation of these ubiquitinated proteins suggests a significant contribution of the ubiquitin-proteasome system in these neuropathological features. In addition, the use of different cellular and animal models of ALS has provided substantial evidence of the involvement of the ubiquitin-proteasome system in the formation of inclusion and neuronal death [197].

\section{Small Molecule Enhancers of 26S Proteasome Activity}

The role of the proteasome in the regulation of cellular functions has made it an important target for the development of new treatments for cancer and neurodegenerative diseases. In addition, understanding proteasome regulation has allowed scientists to probe the mechanism of different cellular processes that involve the proteasome.

Small molecules that directly activate the $26 \mathrm{~S}$ proteasome are rare and most of the well-studied approaches to enhance the $26 \mathrm{~S}$ proteasome involve indirect activation by modulation of post-translational modification and by genetic manipulation. A recent review highlights some of the cellular mechanisms that activate 26S proteasomes [198]. In this review, we will focus on small molecules that activate the $26 \mathrm{~S}$ proteasome.

\subsection{Indirect Activation of $26 S$ Proteasome \\ 3.1.1. Inhibition of Deubiquitinase}

Deubiquitinating enzymes (DUBs) play a critical role in the ubiquitin-proteasome system (UPS). The 19S RP of the proteasome uses deubiquitinase activity to remove and recycle polyubiquitin from protein substrates that are condemned for proteolysis [199]. There are three essential DUBs: RPN11, UCH37, and USP14 that are associated with the 19S RP of human proteasome $[124,200,201]$. The main function of these DUBs is to 
remove monoubiquitin and polyubiquitin chains from substrates tagged for proteasomal degradation [202-205]. USP14, a DUB of the cysteine protease class, interacts reversibly with the proteasome $[124,206-208]$ and it cleaves the ubiquitin chain off the targeted protein before degradation by the proteasome $[209,210]$, thereby inhibiting the degradation of ubiquitin-protein conjugates in vitro and in vivo [124]. Unlike USP14, the RPN11, a DUB of the metalloprotease class, is part of the 19S RP and cleaves the ubiquitin chain after degradation has been initiated by the proteasome [200]. The mechanism of action of UCH37 is not completely understood yet but this DUB could edit the ubiquitin chains and either prevent the protein from being degraded or enhance its degradation depending on the proteasome needs $[200,211,212]$.

A study conducted in 2010 showed that USP14 inhibits protein degradation by the proteasome in murine embryonic fibroblasts. In the same study, the authors showed that inhibition of USP14 by 1-[1-(4-fluorophenyl)-2,5-dimethylpyrrol-3-yl]-2-pyrrolidin-1ylethanone (IU1, Figure 3, compound 1) drastically stimulate the degradation of oxidized proteins by the proteasome [124]. IU1 was identified as a USP14 inhibitor from highthroughput screening (HTS) of over sixty-three thousand compounds for their ability to inhibit USP14. From the HTS, 215 compounds were identified as true inhibitors of USP14, however, screening of the hit compounds against several DUBs only provided three compounds as selective inhibitors of USP14. IU1 was found to be the most active of the three with $\mathrm{IC}_{50}$ of $4-5 \mu \mathrm{M}$ [124]. Further optimization of IU1 has led to the discovery of more potent analogues such as IU1-47 (IC 50 of $0.6 \mu \mathrm{M}$ ) (Figure 3, compound 2) [213], IU1-248 $\left(\mathrm{IC}_{50}\right.$ of $0.83 \mu \mathrm{M}$ ) (Figure 3, compound 3) [214], and 1B10 and 1D18 (Figure 3, compound 4 \& 5 respectively) which have better membrane permeability [215]. A recent review by Moon et al. [210], is focused on small molecules that inhibit proteasome-associated deubiquitinase and can be consulted for more information on DUB inhibitors.

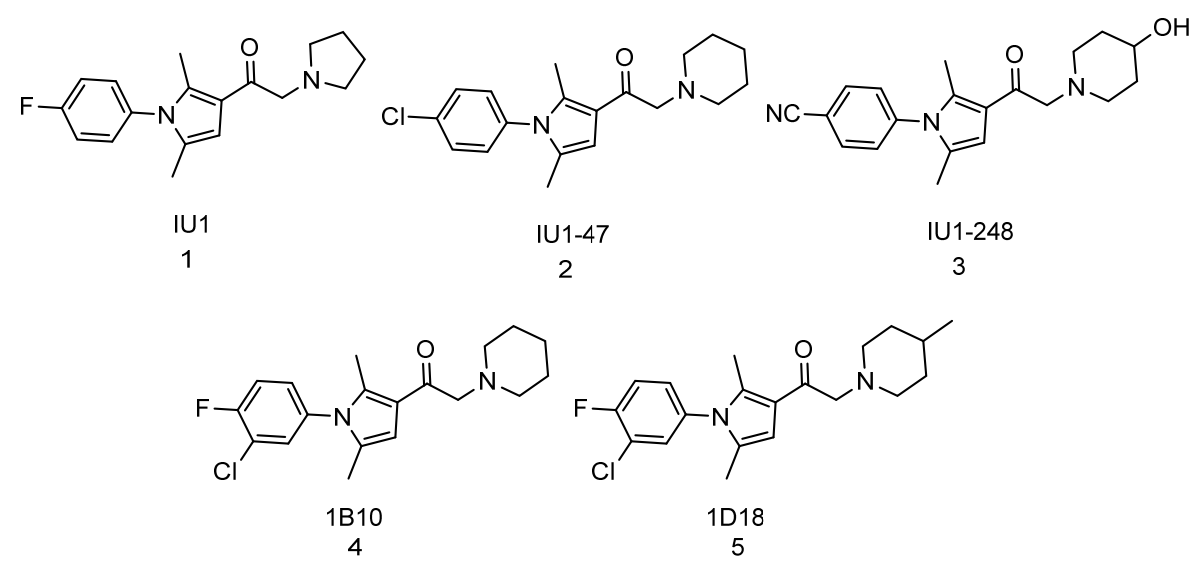

Figure 3. Small molecules inhibitors of deubiquitinase enzymes (DUBs).

In a recent study by Kim et al. [216], proteasome-mediated proteolysis was increased by knocking down USP14 with small interfering RNA (siRNA) which led to a significant impairment of autophagic flux. This proteasome activation led to an increase in the microtubule-associated protein tau (MAPT) degradation and a decrease in the concentration of its oligomeric forms. This result is also consistent with Boselli et al.'s observation that USP14 inhibition enhances tau degradation in cultured neurons [213].

\subsubsection{Modulation of cAMP-Dependent Protein Kinase A (PKA) and cGMP-Dependent} Protein Kinase G

Phosphorylation of proteasome subunits was recently established as a promising way to proteasome regulation [217]. The phosphorylation of Ser-14 of Rpn6, a subunit of $19 S$ regulatory particle, by cAMP-dependent PKA has been shown to enhance the hydrolysis of polyubiquitinated proteins and small peptides in cells and in vivo studies [218-221]. In addition, impeding the phosphorylation of Thr- 25 of Rpt 3 by dual-specificity tyrosine-regulated 
kinase 2 (DYRK2) [222,223] and Ser-120 of Rpt6 by calcium/calmodulin-dependent protein kinase II (CaMKII) [224,225] or PKA [119] have been shown to impair proteasome proteolytic capacity and impedes cell proliferation. Small molecules that raise cAMP have therapeutical promise because they enhance the capacity of cell cultures [220] and mouse brains $[119,226]$ to degrade misfolded proteins such as tau, which has been implicated in the pathogenesis of Alzheimer's disease.

Small molecule inhibitors of phosphodiesterase have been found to increase proteasome function by cAMP/PKA-mediated phosphorylation. Rolipram (Figure 4, compound 6) is an example of phosphodiesterase type-4 inhibitor (PDE4) that was developed as an antidepressant drug in the early 1990s [227]. A study shows that Rolipram decreases the level of insoluble tau and improves cognitive performance in mice by increasing proteasome function through activating cAMP-PKA signaling [119]. Cilostazol (Figure 4, compound 7) is another phosphodiesterase type-3 inhibitor (PDE3). Administration of Cilostazol in rTg4510 mice also showed improved cognitive performance and increased proteasome function through the cAMP/PKA pathway [226]. This small molecule was approved by the FDA to treat intermittent claudication and can also be used for secondary stroke prevention [228]. In late 2020, the FDA completed the clinical trial to determine the therapeutical use of cilostazol for patients with mild cognitive impairment [229].

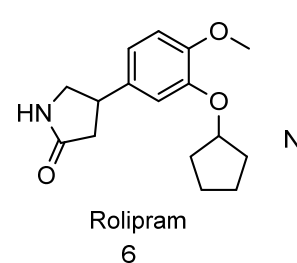

6<smiles>CN1CC(=O)N2C(c3ccc4c(c3)OCO4)c3[nH]c4ccccc4c3C[C@]2(C)C1=O</smiles>
9<smiles>O=C1CCc2cc(OCCCCc3nnnn3C3CCCCC3)ccc2N1</smiles>

7

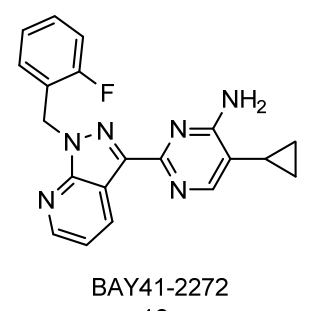

10<smiles>CCCc1nn(C)c(-c2nc(-c3cc(S(=O)(=O)N4CCN(C)CC4)ccc3OCC)[nH]c(=O)c2C)c1OCC</smiles>

8<smiles>O=C(O)CCCCN(CCc1ccccc1OCc1ccc(CCc2ccccc2)cc1)Cc1ccc(C(=O)O)cc1</smiles>

11

Figure 4. Rolipram (6) and Cilostazol (7) are examples of phosphodiesterase type-4 (PDE4) inhibitors. Molecules that inhibit PDE4 raise cAMP/PKA-mediated phosphorylation which increases the rate of degradation of IDPs and misfolded proteins in cellular assays and animal models. Sildenafil (8), Tadalafil (9), BAY41-2272 (10), and Cinaciguat (11) are molecules that raise cGMP level and induce cGMP-mediated proteasome activation.

Like cAMP-mediated modulation of $26 \mathrm{~S}$ proteasome, small molecules that raise cGMP and activate PKG were recently shown to enhance proteasome proteolytic activity without affecting lysosomal degradation and increase the rate of degradation of both short-lived and long-lived proteins, including tau and mutant Htt. [198,230]. In the study conducted by VerPlank et al. [230], treatment of human neuroblast cells (SH-SY5Y) with molecules that raises cGMP such as sildenafil (Figure 4, compound 8) or tadalafil (Figure 4, compound 9) which are phosphodiesterase type-5 inhibitors (PDE5), or BAY41-2272 (Figure 4, compound 10) and cinaciguat, (Figure 4, compound 11) which are stimulators of soluble guanylyl cyclases, led to a rapid increase in proteasomal activity in cell lysates. However, unlike phosphorylation of Rpn6 by PKA [220,221], Rpt3 by DYRK2 [222,223], or Rpt6 by CaMKII) [224,225] or PKA [119], phosphorylation of Rpn6, Rpt3, or Rpt6 subunit was not observed in the PKG pathway [230]. Overexpression of PKG in SH-SY5Y and HEK293 cells led to an increase in the level of phosphorylated proteins compared to cells that were transfected with empty vectors during proteasome preparations. Thus, the $26 \mathrm{~S}$ proteasome 
subunit or an associated protein that is phosphorylated in the cGMP-mediated proteasome activation is still unknown and the mechanism of action remains unclear.

\subsubsection{Inhibition of p38 Mitogen-Activated Protein Kinase (MAPK)}

MAPKs are enzymes that phosphorylate the hydroxyl group of threonine and serine residues in proteins. These kinases play an important role in the control of cell proliferation and apoptosis. The p38 MAPK is involved in a signaling pathway that regulates various biological functions including biosynthesis of cytokinesis such as interleukin-1 $\beta$ (IL-1 $\beta$ ) and tumor necrosis factor- $\alpha$ (TNF- $\alpha$ ) [231,232]. The activation of the p38 MAPK pathway as a defense to osmotic stress has been shown to lead to phosphorylation of 19S RP at Thr-273 of the Rpn2 subunit, which resulted in the inhibition of the $26 \mathrm{~S}$ proteasome proteolytic activity [233].

In ALS and AD, the over-activation of the p38 MAPK pathway has been reported in animal models and postmortem brains of AD patients [195,234-236]. The activation of the p38 MAPK pathway in cell lines and animal models has led to tau phosphorylation, neuroinflammation, neurotoxicity, and synaptic dysfunction, which are events associated with Alzheimer's disease. Therefore, the search for p38 MAPK inhibitors became a novel approach for targeting neurodegenerative diseases [237].

In 2017, Leestemaker et al. [122] discovered imidazole inhibitors of p38 MAPK as enhancers of $26 \mathrm{~S}$ proteasome proteolytic activity. The compounds were identified from high-throughput screening of over 2750 compounds using a proteasome activity-based probe ( $\mathrm{Me}_{4}$ BodipyFLAhx ${ }_{3} \mathrm{~L}_{3} \mathrm{VS}$ ) that covalently binds to proteasome catalytic sites in an activity-dependent manner in living cells. The group found that PD169316 (Figure 5, compound 12), a known inhibitor of p38 MAPK and its structural analogues, SB202190 (Figure 5, compound 13), and SB203580 (Figure 5, compound 14), increases the proteolytic activity of the proteasome in a dose-dependent manner in MelJuSo cells. Further characterization of these compounds showed that they increase proteasome proteolytic activity by inhibiting the p38 MAPK pathway without affecting cell viability, subunits abundance, and the overall level of ubiquitinated proteins [122]. Similarly, Huang et al. [238], demonstrated that treatment of HAP 40 depleted cells with p38 MAPK inhibitor, PD169316, increases the CT-L activity of the proteasome and enhances degradation of both soluble and aggregated forms of mutant Htt in a Huntington's disease model. These data suggest that the regulation of the p38 MAPK pathway could be a potential way of modulating proteasome-mediated proteolytic activity.

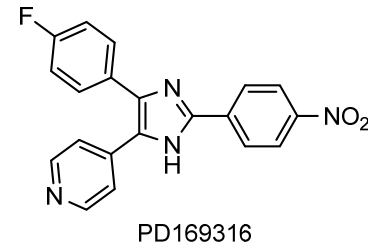

12

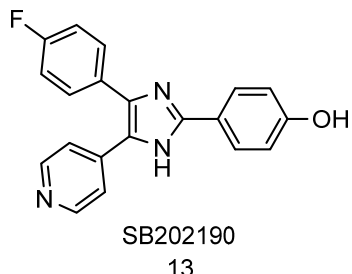

13

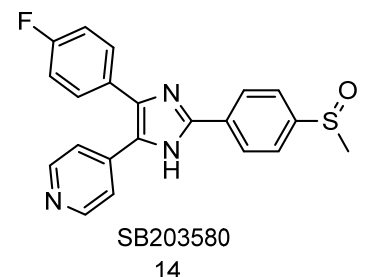

14

Figure 5. Imidazole inhibitors of p38 MAPK that enhances proteasome activities.

\subsubsection{Proteasome Activation by Genetic Manipulation}

Another approach to enhancing proteasome proteolytic activity is by proteasome subunit overexpression. Overexpression of $\beta 5 \mathrm{i}$ subunit in HeLa cells and lymphoblasts has led to an increase in the CT-L and T-L activities of the proteasome $[239,240]$. Previous studies also showed that stable overexpression of the $\beta 5$ subunit in human fibroblast cell lines increased the level of other $\beta$ subunits, increasing the overall proteolytic activity of the three catalytic sites [241]. Furthermore, overexpression of the 19S RP subunit PSMD11/Rpn6 increases proteasome assembly and proteolytic activity in human embryonic stem cells [242].

Small molecule activation of the transcription factor NRF2, nuclear factor erythroid 2-related factor 2, enhances the expression of the 20S and 19S proteasome particles and increases the proteolytic activity of the proteasome in cells containing NRF2. 18 $\alpha$-glycyrrhetinic 
acid (18 $\alpha$-GA) has been shown to increase proteasome proteolytic activities from 1.5- to 1.8-fold, with the activity of the caspase-like site being the most affected in wide-type HFL-1 human fibroblasts. In addition, the increase in the proteasome proteolytic activity was not observed when NRF2 was knockdown using siRNA in HFL-1 cells and the cells were treated with $18 \alpha-\mathrm{GA}$, further confirming the upregulation of proteasome proteolytic activity through NRF2 activation [243]. The activation of NRF2 increases the level of $20 S$ proteasome subunits: $\alpha 4, \beta 1, \beta 2$, and $\beta 5$ in both human fibroblasts [243] and mice liver [244], and the 19S subunits: Rpt2, Rpt5, and Rpn11 in mice liver [244]. The expression of antioxidant enzymes such as UDP-glucuronosyltransferase (UGT) [245], glutathione S-transferase (GST) [246], and NAD(P)H quinone oxidoreductase 1 [247], to name a few, are also controlled by this transcription factor. Activation of NRF2 by tert-Butylhydroquinone ( $t-B H Q)$ and sulforaphane increases proteasome proteolytic activity in human embryonic stem cells (hESCs) [248] and also protects against oxidative stress [249].

\section{Small Molecule Enhancers of 20S Proteasome Activity}

\subsection{Sodium Dodecyl Sulfate (SDS)}

SDS (sodium dodecyl sulfate), also known as SLS (sodium lauryl sulfate), is a synthetic organosulfate salt used in cleaning, pharmaceutical, and food products. In 1988, Tanaka et al. [250] showed that $20 \mathrm{~S}$ proteasome proteolytic activity could be enhanced at a low concentration of SDS (0.04-0.08\%) in biochemical assays. However, at higher SDS concentrations, the activity of the proteasome is lost, and the SDS inhibits the proteasome [251]. SDS is an invaluable in vitro tool that is used by most researchers to activate the proteasome as means to test compounds for subsequent proteasome inhibition. It is believed that SDS induces gate opening of the proteasome by partial denaturation of the $20 \mathrm{~S}$ to facilitate substrate entrance into the catalytic core. However, the actual mechanism of SDS proteasome activation is still unclear and considering that SDS is a detergent, it should not really be considered as a small molecule activator of the $20 \mathrm{~S}$ proteasome.

\subsection{Natural Product-Based Activators}

Several natural products have been identified as $20 \mathrm{~S}$ proteasome activators, some of which include betulinic acid (Figure 6, compound 15) [252], ursolic acid (Figure 6, compound 16) [127], and oleuropein (Figure 6, compound 17) [253]. Betulinic acid is a triterpene isolated from the bark of Betula pubescens (commonly known as white birch). It was reported as a selective inhibitor of human melanoma and it has been demonstrated to induce programmed cell death in human neuroblastoma and neuroectodermal tumor cells [254]. Betulinic acid is one of the first reported enhancers of the $20 \mathrm{~S}$ proteasome. A small peptide assay using Suc-Leu-Leu-Val-Tyr-AMC (used to determine the CT-L activity of the proteasome) showed that's betulinic acid enhances the CT-L activity of the proteasome with $\mathrm{EC}_{50}$ of approximately $2.5 \mu \mathrm{g} / \mathrm{mL}$. Unfortunately, several chemical modifications to enhance the activity of betulinic acid resulted in compounds that inhibit the proteasome [252]. Like betulinic acid, ursolic acid is another triterpenoid that enhances the activity of the $20 \mathrm{~S}$ proteasome. Ursolic acid is similar in structurally to betulinic acid, and they both enhance the CT-L activity of the 20S proteasome [127,252]. Although both betulinic acid and ursolic acid showed good activity in small peptide assay, unfortunately, betulinic acid did not show any activity for the turnover of misfolded proteins in vitro and in vivo [72].

In addition, other natural compounds have been identified as $20 \mathrm{~S}$ proteasome agonists. Some of these compounds include lipids [255] and fatty acids [256]. In 1993, Ruiz de Mena et al. [255] studied the effect of phospholipids on the T-L, CT-L, and C-L activities of the proteasome in rat liver. In the study, the team identified cardiolipin (diphosphatidylglycerol) as a strong CT-L enhancer (up to 60-fold enhancement) and C-L enhancer (up to 30-fold enhancement). SDS and cardiolipin activation was shown to be additive and at either optimal or suboptimal concentrations of both compounds. Furthermore, fatty acids such as oleic, linoleic, and linolenic acids isolated from spinach leaves were found to 
increase proteasome-mediated substrate degradation by enhancing CT-L and C-L activities at about one-third to one-sixth the required concentration of SDS. Unlike SDS, at extremely low concentration $(0.0007-0.0025 \%, \sim 25-90 \mu \mathrm{M})$, the T-L catalytic site is inhibited and the degradation of Boc-L-R-R-AMC is prevented [256].

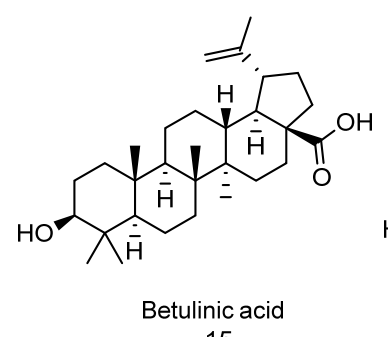

15

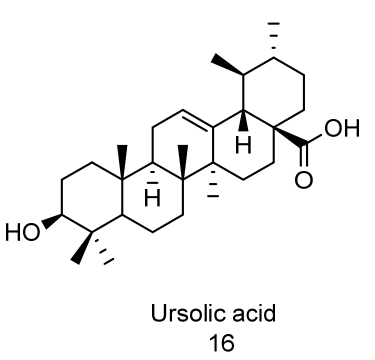

16

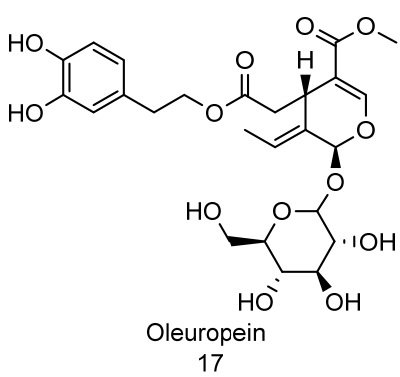

17

Figure 6. Natural product-based activators of 205 proteasome.

\section{3. $A M-404$ and $M K-886$}

Although many compounds show increased peptide cleavage activities using the standard aminomethyl coumarin tagged small peptide substrates, most have failed to demonstrate an increase in proteolytic activity under physiological conditions. One likely explanation is that the small peptide probes, used for detection of in vitro proteasome proteolytic activity, may be small enough to inadvertently enter the CP-proteolytic cavity following minor conformational changes to the gate. Trader and Kodadek developed a follow-up assay that uses larger peptides with a single cleavage site and uses LC-MS to monitor proteasome proteolytic activity over time. They also validated molecules from LC-MS assay for their ability to turnover of $\alpha$-synuclein in cells by monitoring the appearance of free GFP which correlates to the number of $\alpha$-synuclein that was degraded. Using these assays, the lab was able to identify small molecules capable of increasing $20 \mathrm{~S}$ mediated proteolytic activity [72]. The authors screened 726 compounds in the NIH Clinical Collection and identified AM-404 (Figure 7, compound 18) and MK-886 (Figure 7, compound 19) as "true" proteasome enhancers. The study showed both compounds increase the proteolytic activity of the $20 \mathrm{~S}$ proteasome by 3- to 4-folds with an $\mathrm{EC}_{50}$ of 32 $\mu \mathrm{M}$, and they also enhance the degradation of $\alpha$-synuclein in cell culture [72].
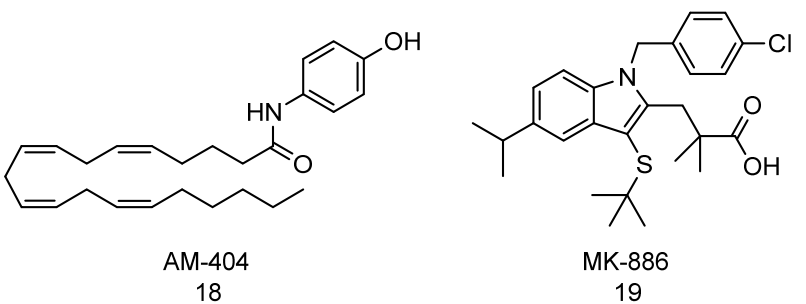

Figure 7. Structure of AM-404 and MK-886.

Recently, the Trader's lab investigated the structural component of AM-404 needed to enhance the proteasome proteolytic activity. In the study, they synthesized various derivatives of AM-404 by varying the aliphatic chain length, degree of unsaturation, and substitutions. They illustrated the importance of the aliphatic chain length and the cisalkene at C8 of the aliphatic chain in stimulating the $20 \mathrm{~S}$ proteasome [126].

\subsection{Imidazolines}

Imidazolines are an important class of compounds that are found in various natural and synthetic bioactive molecules $[257,258]$. This class of compounds displays a wide range of biological activities including proteasome and NF- $\kappa$ B modulation [259-261], and therapeutic significance such as antifungi [262], antitumor [263], antihelminthics [264], antihyperglycemic [265], and antihypertensive activity [266]. 
Our lab reported the imidazoline, TCH-165 (Figure 8, compound 20), as a $20 \mathrm{~S}$ proteasome enhancer as a low $(1.5 \mu \mathrm{M})$ activator of the $20 \mathrm{~S}$ proteasome [70]. TCH-165 enhanced $20 \mathrm{~S}$ mediated degradation of IDPs such as $\alpha$-synuclein, tau, ornithine decarboxylase, and c-Fos in cell cultures. However, it does not affect the degradation of structured proteins such as GAPDH. Treatment of HEK293T cells with TCH-165 showed a time-dependent disassembling of both the singly and doubly capped $26 \mathrm{~S}$ proteasome and showed an increase in the free 20S CP. TCH-165 prevents the binding of the 19S RP to the 20S proteasome suggesting that the molecule binds directly on the $\alpha$-ring of the 20S CP and shifts the equilibrium between $26 \mathrm{~S}$ and $20 \mathrm{~S}$ proteasomes towards an activated 20S CP. To gain insight into the mechanism of $20 \mathrm{~S}$ proteasome activation, atomic force microscopy (AFM) imaging revealed that the ratio of open to closed 205 proteasome increases in a dose-dependent manner when treated with TCH-165 at concentrations as low as $200 \mathrm{nM}$ [70]. This further supports that TCH-165 induces the open gate conformation of the 20S CP. It is also important to note that this is the only small molecule with biophysical data (atomic force microscopy (AFM) imaging) that support gate opening of the 20S proteasome [70].

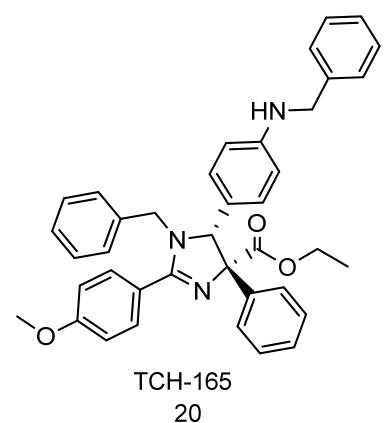

Figure 8. Imidazoline TCH-165 enhances proteasome activities and degrades intrinsically disordered proteins.

\subsection{Chlorpromazines}

During the search for proteasome activators, our lab screened the NIH Clinical Collection and Prestwick libraries, where we identified chlorpromazine (Figure 9, compound 21) and related phenothiazines as $20 \mathrm{~S}$ proteasome activators inducing up to 20-fold activity [69]. Chlorpromazine is an FDA-approved drug that is used in the treatment of schizophrenia or manic-depression in adults. Chlorpromazine is believed to be a dopamine antagonist with some antiserotonergic and antihistaminergic properties [267].
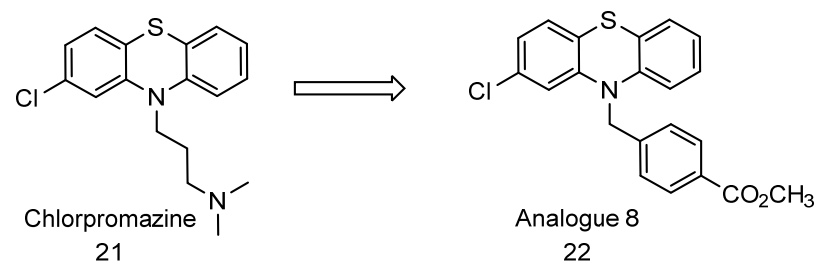

Figure 9. Structure of chlorpromazine and a chlorpromazine analogue 8.

Chlorpromazine and related phenothiazines preferentially enhance the CT-L activity of the proteasome and promote degradation of IDPs, such as $\alpha$-synuclein and tau but not structured proteins in in vitro assays. Chemical modification of chlorpromazine abrogated its dopamine $\mathrm{D} 2 \mathrm{R}$ receptor activity while preserving its ability to enhance the $20 \mathrm{~S}$ proteolytic activity. Analogue 8 (Figure 9, compound 22), an analogue of chlorpromazine with physiological insignificant potency for dopamine receptor $\left(K_{i} \geq 250 \mu \mathrm{M}\right)$ showed better efficacy with about 10-fold maximum enhancement and $\mathrm{EC}_{200}$ (concentration where the $20 \mathrm{~S}$ mediated proteolysis is increased by 2 -fold or $200 \%$ ) of $13.5 \mu \mathrm{M}$.

Interestingly, a structural analogue of chlorpromazine, methylene blue, was also found to enhance the CT-L and T-L activity of the $20 \mathrm{~S}$ proteasome. Methylene blue was also 
found to decrease the level of $\beta$-amyloid and increase learning and memory in 3xTg-AD mouse model but does not affect tau phosphorylation in vivo [268]. A recent study also showed that methylene blue inhibits caspase-6-induced neurodegeneration, decreases neuroinflammation, and prevents cognitive impairment in mice [269].

\subsection{Dihydroquinazolines}

The 3,4-dihroquinazoline compounds are found in several natural products and synthetic compounds with various biological properties. Members of this class of compounds have biological properties that includes antifungal [270], antiparasitic [271], antitumor [272-278], and antiviral activities [279,280].

Earlier this year, Mosey et al. synthesized and evaluated several dihydroquinoline analogues as $20 \mathrm{~S}$ proteasome enhancers $[125,281]$. In this study, they were able to identify several promising $20 \mathrm{~S}$ activators with the most potent being dihydroquinazoline 18 (Figure 10, compound 23), doubling proteasome proteolytic activity at $1.3 \mu \mathrm{M}\left(\mathrm{EC}_{200}\right.$ $1.3 \mu \mathrm{M})$. The dihydroquinazolines enhance the three catalytic sites activity of the $20 \mathrm{~S}$ proteasome and increase the degradation of $\alpha$-synuclein, the IDP identified in the pathogenesis of Parkinson's disease.

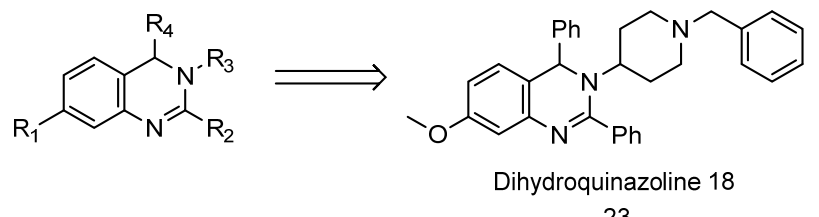

23

Figure 10. Structure of dihydroquinoline scaffold and dihydroquinoline 18 (compound 23).

\subsection{Fluspirilene and Acylfluspirilene}

Earlier this year, the Tepe group identified fluspirilene (Figure 11, compound 24) and its synthetic analogues which were capable of enhancing $20 S$ proteasome proteolytic activity and even restoring the proteolytic activity of $20 \mathrm{~S}$ proteasome impaired by IDP oligomers [132]. Fluspirilene and its amide derivative, acylfluspirilene (Figure 11, compound 25) activate the three catalytic sites of 20S CP and prevent IDP aggregation and oligomerization. Interestingly, acylfluspirilene exhibits more potency $\left(\mathrm{EC}_{200} 1.9 \mu \mathrm{M}\right) \mathrm{com}$ pared to fluspirilene and a better maximum fold enhancement of greater than 20-fold. Furthermore, molecular docking shows that fluspirilene and acylfluspirilene bind to the $\alpha 2-3$ intersubunit pocket of the $20 \mathrm{SCP}$, which is different from the previously reported $20 \mathrm{~S}$ enhancers, TCH-165, dihydroquinoline, and chlorpromazine, which bind in the $\alpha 1-2$ pocket of the proteasome. In silico and in vitro structure-activity relationship (SAR) studies indicated the importance of the in-pocket binding interactions of these molecules with the $20 \mathrm{~S}$ proteasome. This group of molecules does not enhance the proteolytic activity of the $26 \mathrm{~S}$ proteasome and may therefore be used to selectively prevent the accumulation of dysregulated intrinsically disordered proteins without affecting regular ubiquitin-dependent protein degradation [132].

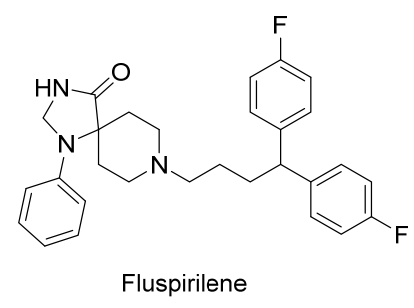

24

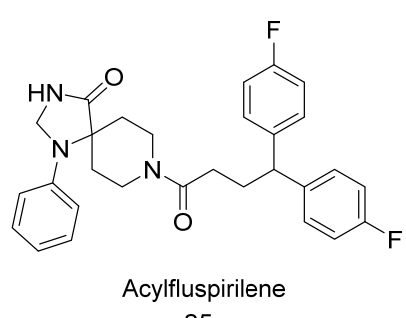

25

Figure 11. Structure of Fluspirilene and Acylfluspirilene. 


\subsection{Pyrazolones}

Pyrazolones are a rare class of compounds that enhance proteasome activation. This class of molecule was first discovered as proteasome activator in 2014 by the Silverman group and as potential compounds for the treatment of ALS [71]. The pyrazolones (Figure 12, compound 26-28) were shown to protect neurons in PC12-SOD1 ${ }^{\mathrm{G} 93 \mathrm{~A}}$ cells in cellular models of ALS. The compounds also increased ALS transgenic mouse survival by $13 \%$, further confirming their potential in the development of ALS therapeutics. During the mechanistic investigation of CMB-087229 (Figure 12, compound 27), the compound was found to antagonize $\mathrm{G}$ protein-coupled receptor metabotropic glutamate receptor 5 $\left(\mathrm{mGluR}_{5}\right)$, a previously identified target in ALS therapeutic [282], to about $65 \%$ at $10 \mu \mathrm{M}$ concentration. The group investigated if $\mathrm{mGluR}_{5}$ was the target of the pyrazolones by screening known mGluR $_{5}$ antagonists in their cell-based assay. However, the screened $\mathrm{mGluR}_{5}$ receptor antagonists (including MPEP and fenobam) showed no activity in the assay. Based on the result, it was concluded that the antagonism of the $\mathrm{mGluR}_{5}$ is unlikely to be the mode of action of the pyrazolones. Pull down experiments indicated several $26 \mathrm{~S}$ proteasome regulatory subunits as a possible target for the pyrazolones. The pyrazolones were able to reverse bortezomib-induced cytotoxicity in the PC12 cells, further supporting evidence that their mechanism of action involved proteasome activation [283].<smiles>Cc1cc(C)c(SCc2cc(=O)[nH][nH]2)cc1Cl</smiles>

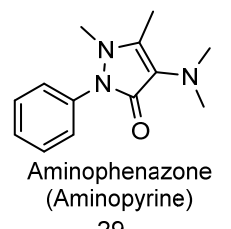

29<smiles>CN1CC(NC(=O)c2cccnc2)C(=O)N1c1ccccc1</smiles>

Figure 12. Structure of pyrazolones that have been shown to increase proteasome activities.

Following up on Silverman's discovery, Santoro et al. [284] screened a small library of structurally-related pyrazolones for proteasome enhancement and neuroprotection against amyloid-induced toxicity in neuroblastoma SH-SY5Y cells. The group reported that the aminopyrine analogue (Figure 12, compound 29) and nifenazone (Figure 12, compound 30) displayed up to twofold induction of $26 \mathrm{~S}$ proteasome proteolytic activity in cells. Using docking studies coupled with Saturation Transfer Difference (STD) NMR experiments, the group proposed that aminopyrine enhances the $20 \mathrm{~S}$ proteasome by a mechanism involving binding to the $\alpha$-ring surfaces of the proteasome; however, only a marginal increase in activity was observed $(<30 \%$ increase at $10 \mu \mathrm{M})$ in a purified proteasome assay.

\section{Conclusions}

Efficient proteasome function is critical in maintaining healthy cellular homeostasis. Dysregulation of protein or proteasome impairment can result in a toxic accumulation of unwanted proteins, which is observed in the pathogenesis of different neurodegenerative diseases and aging. Enhancing the proteolytic activity of the proteasome by increasing its capacity, accessibility, or the rate at which it degrades has long been hypothesized as a means to prevent the accumulation of dysregulated IDPs. More recently, researchers from various labs have explored the use of small molecules to induce protein proteolysis. Small molecule proteasome agonists can enhance the proteolytic clearance of unwanted proteins and restore homeostasis. Small molecule enhancers of the $26 \mathrm{~S}$ proteasome are described 
herein which mainly induce enhanced 26S-mediated proteolysis of ubiquitinated proteins via an indirect mechanism of proteasome activation.

Small molecule inhibitors of deubiquitinases prevent proteins marked for ubiquitindependent degradation fromescaping their fate. Even though there are no approved therapies yet based on deubiquitinating enzyme (DUB) inhibitors, this is an emerging field with great significance. Small molecule regulation of upstream signaling pathways, including cAMP-depending protein kinase A and c-GMP-dependent protein kinase G, affect the phosphorylation of the proteasome regulatory particles. As a result, small molecule regulators of phosphodiesterase type-3 (PDE3) can therefore indirectly increase the rate of substrate degradation by the proteasome. Small molecules that directly interact with the $26 \mathrm{~S}$ proteasome and enhance the rate of $26 \mathrm{~S}$ proteasome-mediated protein degradation are less known and likely a fruitful field for exploration.

Whereas the $26 \mathrm{~S}$ proteasome targets ubiquitinylated protein substrates, the 20S proteasome is limited to the degradation of only disordered proteins. Several small molecule enhancers of $20 S$ proteasome-mediated protein degradation have been identified in the literature. We summarized herein several different classes of small molecule $20 \mathrm{~S}$ proteasome enhancers that induce 20S-mediated degradation of dysregulated intrinsically disordered proteins by direct interaction with the $20 \mathrm{~S}$ core particle.

The activation of the proteasome by small molecules is a relatively new field in science. Its potential as a therapeutic approach is still unknown and the consequences of chronic exposure to proteasome enhancers are not known. However, considering the possibility of treating multiple disorders for which there are currently no treatment options available, this approach has enormous potential. However, as in all new fields, the approach still needs further validation, in vivo studies in particular, to fully understand its therapeutic potential and limitation. In addition, more studies are needed to elucidate the mechanistic details of small molecule proteasome activation and its overall cellular consequences.

Author Contributions: D.E.G. was responsible for writing the article. J.J.T. is founder and owner of Portera Therapeutics. All authors have read and agreed to the published version of the manuscript.

Funding: This research was funded in part by NIH, R01 AG066223. DEG was funded in part by NIH T32 GM142521.

Acknowledgments: The authors gratefully acknowledge financial support from the National Institutes of Health.

Conflicts of Interest: The authors declare no conflict of interest.

\section{References}

1. Hetz, C.; Glimcher, L.H. Protein homeostasis networks in physiology and disease. Curr. Opin. Cell. Biol. 2011, 23, 123-125. [CrossRef]

2. McNaught, K.S.P.; Olanow, C.W.; Halliwell, B.; Isacson, O.; Jenner, P. Failure of the ubiquitin-proteasome system in Parkinson's disease. Nat. Rev. Neurosci. 2001, 2, 589-594. [CrossRef] [PubMed]

3. Saez, I.; Vilchez, D. The Mechanistic Links Between Proteasome Activity, Aging and Age-related Diseases. Curr. Genomics 2014, 15, 38-51. [CrossRef] [PubMed]

4. LaPlante, G.; Zhang, W. Targeting the Ubiquitin-Proteasome System for Cancer Therapeutics by Small-Molecule Inhibitors. Cancers 2021, 13, 3079. [CrossRef] [PubMed]

5. Momtaz, S.; Memariani, Z.; El-Senduny, F.F.; Sanadgol, N.; Golab, F.; Katebi, M.; Abdolghaffari, A.H.; Farzaei, M.H.; Abdollahi, M. Targeting Ubiquitin-Proteasome Pathway by Natural Products: Novel Therapeutic Strategy for Treatment of Neurodegenerative Diseases. Front. Physiol. 2020, 11, 361. [CrossRef]

6. Rao, G.; Croft, B.; Teng, C.; Awasthi, V. Ubiquitin-Proteasome System in Neurodegenerative Disorders. J. Drug Metab. Toxicol. 2015, 6, 187. [PubMed]

7. Huang, Q.; Figueiredo-Pereira, M.E. Ubiquitin/proteasome pathway impairment in neurodegeneration: Therapeutic implications. Apoptosis 2010, 15, 1292-1311. [CrossRef]

8. Njomen, E.; Tepe, J.J. Proteasome activation as a new therapeutic approach to target proteotoxic disorders. J. Med. Chem. 2019, 62, 6469-6481. [CrossRef] 
9. Kisselev, A.F.; Akopian, T.N.; Woo, K.M.; Goldberg, A.L. The sizes of peptides generated from protein by mammalian 26 and 20 S proteasomes. Implications for understanding the degradative mechanism and antigen presentation. J. Biol. Chem. 1999, 274, 3363-3371. [CrossRef]

10. Kumar Deshmukh, F.; Yaffe, D.; Olshina, M.A.; Ben-Nissan, G.; Sharon, M. The Contribution of the 20S Proteasome to Proteostasis. Biomolecules 2019, 9, 190. [CrossRef]

11. Hershko, A.; Ciechanover, A. The ubiquitin system. Annu. Rev. Biochem. 1998, 67, 425-479. [CrossRef]

12. Stewart, M.D.; Ritterhoff, T.; Klevit, R.E.; Brzovic, P.S. E2 enzymes: More than just middle men. Cell Res. 2016, 26, 423-440. [CrossRef] [PubMed]

13. Adapted from “Ubiquitin Proteasome System”, by BioRender.com. Available online: https://app.biorender.com/biorendertemplates (accessed on 19 October 2021).

14. Komander, D. The emerging complexity of protein ubiquitination. Biochem. Soc. Trans. 2009, 37, 937-953. [CrossRef] [PubMed]

15. Peng, J.; Schwartz, D.; Elias, J.E.; Thoreen, C.C.; Cheng, D.; Marsischky, G.; Roelofs, J.; Finley, D.; Gygi, S.P. A proteomics approach to understanding protein ubiquitination. Nat. Biotechnol. 2003, 21, 921-926. [CrossRef] [PubMed]

16. Chau, V.; Tobias, J.W.; Bachmair, A.; Marriott, D.; Ecker, D.J.; Gonda, D.K.; Varshavsky, A. A multiubiquitin chain is confined to specific lysine in a targeted short-lived protein. Science 1989, 243, 1576-1583. [CrossRef]

17. Tracz, M.; Bialek, W. Beyond K48 and K63: Non-canonical protein ubiquitination. Cell. Mol. Biol. Lett. 2021, 26, 1. [CrossRef]

18. Komander, D.; Rape, M. The Ubiquitin Code. Annu. Rev. Biochem. 2012, 81, 203-229. [CrossRef] [PubMed]

19. hrower, J.S.; Hoffman, L.; Rechsteiner, M.; Pickart, C.M. Recognition of the polyubiquitin proteolytic signal. EMBO J. 2000, 19, 94-102. [CrossRef]

20. Dimova, N.V.; Hathaway, N.A.; Lee, B.-H.; Kirkpatrick, D.S.; Berkowitz, M.L.; Gygi, S.P.; Finley, D.; King, R.W. APC/C-mediated multiple monoubiquitylation provides an alternative degradation signal for cyclin B1. Nat. Cell Biol. 2012, 14, 168-176. [CrossRef]

21. Shabek, N.; Herman-Bachinsky, Y.; Buchsbaum, S.; Lewinson, O.; Haj-Yahya, M.; Hejjaoui, M.; Lashuel, H.A.; Sommer, T.; Brik, A.; Ciechanover, A. The Size of the Proteasomal Substrate Determines Whether Its Degradation Will Be Mediated by Mono- or Polyubiquitylation. Mol. Cell 2012, 48, 87-97. [CrossRef]

22. Kravtsova-Ivantsiv, Y.; Ciechanover, A. Non-canonical ubiquitin-based signals for proteasomal degradation. J. Cell Sci. 2012, 125, 539-548. [CrossRef] [PubMed]

23. Martinez-Fonts, K.; Davis, C.; Tomita, T.; Elsasser, S.; Nager, A.R.; Shi, Y.; Finley, D.; Matouschek, A. The proteasome 19S cap and its ubiquitin receptors provide a versatile recognition platform for substrates. Nat. Commun. 2020, 11, 477. [CrossRef] [PubMed]

24. Komander, D.; Clague, M.J.; Urbé, S. Breaking the chains: Structure and function of the deubiquitinases. Nat. Rev. Mol. Cell Biol. 2009, 10, 550-563. [CrossRef] [PubMed]

25. Peters, J.M.; Cejka, Z.; Harris, J.R.; Kleinschmidt, J.A.; Baumeister, W. Structural features of the 26S proteasome complex. J. Mol. Biol. 1993, 234, 932-937. [CrossRef]

26. da Fonseca, P.C.; Morris, E.P. Structure of the human 26S proteasome: Subunit radial displacements open the gate into the proteolytic core. J. Biol. Chem. 2008, 283, 23305-23314. [CrossRef] [PubMed]

27. Orlowski, M.; Wilk, S. Catalytic Activities of the 20S Proteasome, a Multicatalytic Proteinase Complex. Arch. Biochem. Biophys. 2000, 383, 1-16. [CrossRef]

28. Dong, Y.; Zhang, S.; Wu, Z.; Li, X.; Wang, W.L.; Zhu, Y.; Stoilova-McPhie, S.; Lu, Y.; Finley, D.; Mao, Y. Cryo-EM structures and dynamics of substrate-engaged human $26 S$ proteasome. Nature 2019, 565, 49-55. [CrossRef]

29. Finley, D.; Chen, X.; Walters, K.J. Gates, Channels, and Switches: Elements of the Proteasome Machine. Trends Biochem. Sci 2016, 41,77-93. [CrossRef]

30. Andres, H.; Goodall, E.A.; Gates, S.N.; Lander, G.C.; Martin, A. Substrate-engaged 26S proteasome structures reveal mechanisms for ATP-hydrolysis-driven translocation. Science 2018, 362, eaav0725. [CrossRef]

31. Eisele, M.R.; Reed, R.G.; Rudack, T.; Schweitzer, A.; Beck, F.; Nagy, I.; Pfeifer, G.; Plitzko, J.M.; Baumeister, W.; Tomko, R.J.; et al. Expanded Coverage of the 26S Proteasome Conformational Landscape Reveals Mechanisms of Peptidase Gating. Cell Rep. 2018, 24, 1301-1315.e1305. [CrossRef]

32. Ding, Z.; Fu, Z.; Xu, C.; Wang, Y.; Wang, Y.; Li, J.; Kong, L.; Chen, J.; Li, N.; Zhang, R.; et al. High-resolution cryo-EM structure of the proteasome in complex with ADP-AlFx. Cell Res. 2017, 27, 373-385. [CrossRef]

33. Huang, X.; Luan, B.; Wu, J.; Shi, Y. An atomic structure of the human 26S proteasome. Nat. Struct. Mol. Biol. 2016, 23, 778-785. [CrossRef] [PubMed]

34. Chen, S.; Wu, J.; Lu, Y.; Ma, Y.-B.; Lee, B.-H.; Yu, Z.; Ouyang, Q.; Finley, D.J.; Kirschner, M.W.; Mao, Y. Structural basis for dynamic regulation of the human $26 S$ proteasome. Proc. Natl. Acad. Sci. USA 2016, 113, 12991. [CrossRef] [PubMed]

35. Ding, Z.; Xu, C.; Sahu, I.; Wang, Y.; Fu, Z.; Huang, M.; Wong, C.C.L.; Glickman, M.H.; Cong, Y. Structural Snapshots of 26S Proteasome Reveal Tetraubiquitin-Induced Conformations. Mol. Cell 2019, 73, 1150-1161.e1156. [CrossRef] [PubMed]

36. Vilchez, D.; Saez, I.; Dillin, A. The role of protein clearance mechanisms in organismal ageing and age-related diseases. Nat. Commun. 2014, 5, 5659. [CrossRef] [PubMed]

37. Bochtler, M.; Ditzel, L.; Groll, M.; Hartmann, C.; Huber, R. The proteasome. Annu Rev Biophys Biomol Struct 1999, $28,295-317$. [CrossRef]

38. Huber, E.M.; Heinemeyer, W.; Li, X.; Arendt, C.S.; Hochstrasser, M.; Groll, M. A unified mechanism for proteolysis and autocatalytic activation in the $20 \mathrm{~S}$ proteasome. Nat. Commun. 2016, 7, 10900. [CrossRef] 
39. Huang, L.; Chen, C.H. Proteasome regulators: Activators and inhibitors. Curr. Med. Chem. 2009, 16, 931-939. [CrossRef] [PubMed]

40. Kane, R.C.; Bross, P.F.; Farrell, A.T.; Pazdur, R. Velcade: U.S. FDA approval for the treatment of multiple myeloma progressing on prior therapy. Oncologist 2003, 8, 508-513. [CrossRef]

41. Bruna, J.; Udina, E.; Alé, A.; Vilches, J.J.; Vynckier, A.; Monbaliu, J.; Silverman, L.; Navarro, X. Neurophysiological, histological and immunohistochemical characterization of bortezomib-induced neuropathy in mice. Exp. Neurol. 2010, 223, 599-608. [CrossRef]

42. Gilmore, T.D.; Herscovitch, M. Inhibitors of NF-kB signaling: 785 and counting. Oncogene 2006, 25, 6887-6899. [CrossRef] [PubMed]

43. Hideshima, T.; Richardson, P.; Chauhan, D.; Palombella, V.J.; Elliott, P.J.; Adams, J.; Anderson, K.C. The proteasome inhibitor PS-341 inhibits growth, induces apoptosis, and overcomes drug resistance in human multiple myeloma cells. Cancer Res. 2001, 61, 3071-3076. [PubMed]

44. Russo, S.M.; Tepper, J.E.; Baldwin, A.S., Jr.; Liu, R.; Adams, J.; Elliott, P.; Cusack, J.C., Jr. Enhancement of radiosensitivity by proteasome inhibition: Implications for a role of NF-kappaB. Int. J. Radiat. Oncol. Biol. Phys. 2001, 50, 183-193. [CrossRef]

45. Sunwoo, J.B.; Chen, Z.; Dong, G.; Yeh, N.; Crowl Bancroft, C.; Sausville, E.; Adams, J.; Elliott, P.; Van Waes, C. Novel proteasome inhibitor PS-341 inhibits activation of nuclear factor-kappa B, cell survival, tumor growth, and angiogenesis in squamous cell carcinoma. Clin. Cancer Res. 2001, 7, 1419-1428.

46. Hideshima, T.; Chauhan, D.; Richardson, P.; Mitsiades, C.; Mitsiades, N.; Hayashi, T.; Munshi, N.; Dang, L.; Castro, A.; Palombella, V.; et al. NF-kappa B as a therapeutic target in multiple myeloma. J. Biol. Chem. 2002, 277, 16639-16647. [CrossRef] [PubMed]

47. Tan, C.; Waldmann, T.A. Proteasome inhibitor PS-341, a potential therapeutic agent for adult T-cell leukemia. Cancer Res. 2002, 62, 1083-1086.

48. Ma, M.H.; Yang, H.H.; Parker, K.; Manyak, S.; Friedman, J.M.; Altamirano, C.; Wu, Z.Q.; Borad, M.J.; Frantzen, M.; Roussos, E.; et al. The proteasome inhibitor PS-341 markedly enhances sensitivity of multiple myeloma tumor cells to chemotherapeutic agents. Clin. Cancer Res. 2003, 9, 1136-1144.

49. Shah, S.A.; Potter, M.W.; McDade, T.P.; Ricciardi, R.; Perugini, R.A.; Elliott, P.J.; Adams, J.; Callery, M.P. 26S proteasome inhibition induces apoptosis and limits growth of human pancreatic cancer. J. Cell. Biochem. 2001, 82, 110-122. [CrossRef]

50. Yang, Y.; Ikezoe, T.; Saito, T.; Kobayashi, M.; Koeffler, H.P.; Taguchi, H. Proteasome inhibitor PS-341 induces growth arrest and apoptosis of non-small cell lung cancer cells via the JNK/c-Jun/AP-1 signaling. Cancer Sci. 2004, 95, 176-180. [CrossRef]

51. Williams, S.A.; McConkey, D.J. The proteasome inhibitor bortezomib stabilizes a novel active form of p53 in human LNCaP-Pro5 prostate cancer cells. Cancer Res. 2003, 63, 7338-7344.

52. Li, B.; Dou, Q.P. Bax degradation by the ubiquitin/proteasome-dependent pathway: Involvement in tumor survival and progression. Proc. Natl. Acad. Sci. USA 2000, 97, 3850-3855. [CrossRef]

53. Breitschopf, K.; Zeiher, A.M.; Dimmeler, S. Ubiquitin-mediated degradation of the proapoptotic active form of bid. A functional consequence on apoptosis induction. J. Biol. Chem. 2000, 275, 21648-21652. [CrossRef] [PubMed]

54. Bianchi, G.; Oliva, L.; Cascio, P.; Pengo, N.; Fontana, F.; Cerruti, F.; Orsi, A.; Pasqualetto, E.; Mezghrani, A.; Calbi, V.; et al. The proteasome load versus capacity balance determines apoptotic sensitivity of multiple myeloma cells to proteasome inhibition. Blood 2009, 113, 3040-3049. [CrossRef] [PubMed]

55. Sha, Z.; Goldberg, A.L. Multiple myeloma cells are exceptionally sensitive to heat shock, which overwhelms their proteostasis network and induces apoptosis. Proc. Natl. Acad. Sci. USA 2020, 117, 21588. [CrossRef] [PubMed]

56. Suraweera, A.; Münch, C.; Hanssum, A.; Bertolotti, A. Failure of amino acid homeostasis causes cell death following proteasome inhibition. Mol. Cell 2012, 48, 242-253. [CrossRef]

57. Aliabadi, F.; Sohrabi, B.; Mostafavi, E.; Pazoki-Toroudi, H.; Webster, T.J. Ubiquitin-proteasome system and the role of its inhibitors in cancer therapy. Open Biol. 2021, 11, 200390. [CrossRef]

58. Fricker, L.D. Proteasome Inhibitor Drugs. Annu. Rev. Pharmacol. Toxicol. 2020, 60, 457-476. [CrossRef]

59. Gandolfi, S.; Laubach, J.P.; Hideshima, T.; Chauhan, D.; Anderson, K.C.; Richardson, P.G. The proteasome and proteasome inhibitors in multiple myeloma. Cancer Metastasis Rev. 2017, 36, 561-584. [CrossRef] [PubMed]

60. Ito, S. Proteasome Inhibitors for the Treatment of Multiple Myeloma. Cancers 2020, 12, 265. [CrossRef]

61. Kaplan, G.S.; Torcun, C.C.; Grune, T.; Ozer, N.K.; Karademir, B. Proteasome inhibitors in cancer therapy: Treatment regimen and peripheral neuropathy as a side effect. Free Radic. Biol. Med. 2017, 103, 1-13. [CrossRef]

62. Manasanch, E.E.; Orlowski, R.Z. Proteasome inhibitors in cancer therapy. Nat. Rev. Clin. Oncol. 2017, 14, 417-433. [CrossRef]

63. Narayanan, S.; Cai, C.-Y.; Assaraf, Y.G.; Guo, H.-Q.; Cui, Q.; Wei, L.; Huang, J.-J.; Ashby, C.R.; Chen, Z.-S. Targeting the ubiquitin-proteasome pathway to overcome anti-cancer drug resistance. Drug Resist. Updates 2020, 48, 100663. [CrossRef] [PubMed]

64. Roeten, M.S.F.; Cloos, J.; Jansen, G. Positioning of proteasome inhibitors in therapy of solid malignancies. Cancer Chemother. Pharmacol. 2018, 81, 227-243. [CrossRef]

65. Sherman, D.J.; Li, J. Proteasome Inhibitors: Harnessing Proteostasis to Combat Disease. Molecules 2020, 25, 671. [CrossRef] [PubMed]

66. Zhang, X.; Linder, S.; Bazzaro, M. Drug Development Targeting the Ubiquitin-Proteasome System (UPS) for the Treatment of Human Cancers. Cancers 2020, 12, 902. [CrossRef] [PubMed] 
67. Hubbell, G.E.; Tepe, J.J. Natural product scaffolds as inspiration for the design and synthesis of 20S human proteasome inhibitors. RSC Chem. Biol. 2020, 1, 305-332. [CrossRef]

68. Jones, C.L.; Tepe, J.J. Proteasome Activation to Combat Proteotoxicity. Molecules 2019, 24, 2841. [CrossRef]

69. Jones, C.L.; Njomen, E.; Sjogren, B.; Dexheimer, T.S.; Tepe, J.J. Small Molecule Enhancement of 20S Proteasome Activity Targets Intrinsically Disordered Proteins. ACS Chem. Biol. 2017, 12, 2240-2247. [CrossRef]

70. Njomen, E.; Osmulski, P.A.; Jones, C.L.; Gaczynska, M.; Tepe, J.J. Small Molecule Modulation of Proteasome Assembly. Biochemistry 2018, 57, 4214-4224. [CrossRef]

71. Trippier, P.C.; Zhao, K.T.; Fox, S.G.; Schiefer, I.T.; Benmohamed, R.; Moran, J.; Kirsch, D.R.; Morimoto, R.I.; Silverman, R.B. Proteasome Activation is a Mechanism for Pyrazolone Small Molecules Displaying Therapeutic Potential in Amyotrophic Lateral Sclerosis. ACS Chem. Neurosci. 2014, 5, 823-829. [CrossRef]

72. Trader, D.J.; Simanski, S.; Dickson, P.; Kodadek, T. Establishment of a suite of assays that support the discovery of proteasome stimulators. Biochim. Biophys. Acta 2017, 1861, 892-899. [CrossRef] [PubMed]

73. López-Otín, C.; Blasco, M.A.; Partridge, L.; Serrano, M.; Kroemer, G. The Hallmarks of Aging. Cell 2013, $153,1194-1217$. [CrossRef]

74. Lee, C.-K.; Klopp, R.G.; Weindruch, R.; Prolla, T.A. Gene Expression Profile of Aging and Its Retardation by Caloric Restriction. Science 1999, 285, 1390-1393. [CrossRef] [PubMed]

75. Bulteau, A.-L.; Lundberg, K.C.; Humphries, K.M.; Sadek, H.A.; Szweda, P.A.; Friguet, B.; Szweda, L.I. Oxidative Modification and Inactivation of the Proteasome during Coronary Occlusion/Reperfusion*. J. Biol. Chem. 2001, 276, 30057-30063. [CrossRef]

76. Wang, X.; Yen, J.; Kaiser, P.; Huang, L. Regulation of the 26S Proteasome Complex During Oxidative Stress. Sci. Signal. 2010, 3, ra88. [CrossRef] [PubMed]

77. Tonoki, A.; Kuranaga, E.; Tomioka, T.; Hamazaki, J.; Murata, S.; Tanaka, K.; Miura, M. Genetic Evidence Linking Age-Dependent Attenuation of the 26S Proteasome with the Aging Process. Mol. Cell. Biol. 2009, 29, 1095-1106. [CrossRef]

78. Bajorek, M.; Finley, D.; Glickman, M.H. Proteasome Disassembly and Downregulation Is Correlated with Viability during Stationary Phase. Curr. Biol. 2003, 13, 1140-1144. [CrossRef]

79. Kayed, R.; Dettmer, U.; Lesné, S.E. Soluble endogenous oligomeric $\alpha$-synuclein species in neurodegenerative diseases: Expression, spreading, and cross-talk. J. Parkinsons Dis. 2020, 10, 791-818. [CrossRef] [PubMed]

80. Ono, K. Alzheimer's disease as oligomeropathy. Neurochem. Int. 2018, 119, 57-70. [CrossRef]

81. Mroczko, B.; Groblewska, M.; Litman-Zawadzka, A.; Kornhuber, J.; Lewczuk, P. Amyloid $\beta$ oligomers (A $\beta O s)$ in Alzheimer's disease. J. Neural Transm. 2018, 125, 177-191. [CrossRef]

82. Gulisano, W.; Maugeri, D.; Baltrons, M.A.; Fà, M.; Amato, A.; Palmeri, A.; D’Adamio, L.; Grassi, C.; Devanand, D.; Honig, L.S. Role of amyloid- $\beta$ and tau proteins in Alzheimer's disease: Confuting the amyloid cascade. J. Alzheimer's Dis. 2018, 64, S611-S631. [CrossRef] [PubMed]

83. Ghag, G.; Bhatt, N.; Cantu, D.V.; Guerrero-Munoz, M.J.; Ellsworth, A.; Sengupta, U.; Kayed, R. Soluble tau aggregates, not large fibrils, are the toxic species that display seeding and cross-seeding behavior. Protein Sci. 2018, 27, 1901-1909. [CrossRef]

84. Forloni, G.; Balducci, C. Alzheimer's disease, oligomers, and inflammation. J. Alzheimer's Dis. 2018, 62, 1261-1276. [CrossRef] [PubMed]

85. Cline, E.N.; Bicca, M.A.; Viola, K.L.; Klein, W.L. The amyloid- $\beta$ oligomer hypothesis: Beginning of the third decade. J. Alzheimer's Dis. 2018, 64, S567-S610. [CrossRef]

86. Choi, M.L.; Gandhi, S. Crucial role of protein oligomerization in the pathogenesis of Alzheimer's and Parkinson's diseases. FEBS J. 2018, 285, 3631-3644. [CrossRef] [PubMed]

87. Castillo-Carranza, D.L.; Guerrero-Muñoz, M.J.; Sengupta, U.; Gerson, J.E.; Kayed, R. $\alpha$-Synuclein oligomers induce a unique toxic tau strain. Biol. Psychiatry 2018, 84, 499-508. [CrossRef] [PubMed]

88. Shafiei, S.S.; Guerrero-Muñoz, M.J.; Castillo-Carranza, D.L. Tau oligomers: Cytotoxicity, propagation, and mitochondrial damage. Front. Aging Neurosci. 2017, 9, 83. [CrossRef]

89. Sengupta, U.; Nilson, A.N.; Kayed, R. The role of amyloid- $\beta$ oligomers in toxicity, propagation, and immunotherapy. EBioMedicine 2016, 6, 42-49. [CrossRef] [PubMed]

90. Ingelsson, M. Alpha-synuclein oligomers-neurotoxic molecules in Parkinson's disease and other Lewy body disorders. Front. Neurosci. 2016, 10, 408. [CrossRef]

91. Caárdenas-Aguayo, M.a.d.C.; Goómez-Virgilio, L.; DeRosa, S.; Meraz-Ríos, M.A. The role of tau oligomers in the onset of Alzheimer's disease neuropathology. ACS Chem. Neurosci. 2014, 5, 1178-1191. [CrossRef]

92. Katzmarski, N.; Ziegler-Waldkirch, S.; Scheffler, N.; Witt, C.; Abou-Ajram, C.; Nuscher, B.; Prinz, M.; Haass, C.; Meyer-Luehmann, M. A $\beta$ oligomers trigger and accelerate A $\beta$ seeding. Brain Pathol. 2020, 30, 36-45. [CrossRef] [PubMed]

93. Haass, C.; Selkoe, D.J. Soluble protein oligomers in neurodegeneration: Lessons from the Alzheimer's amyloid $\beta$-peptide. Nat. Rev. Mol. Cell Biol. 2007, 8, 101-112. [CrossRef] [PubMed]

94. Smith, D.M. Could a common mechanism of protein degradation impairment underlie many neurodegenerative diseases? J. Exp. Neurosci. 2018, 12, 1179069518794675. [CrossRef] [PubMed]

95. Gerson, J.E.; Farmer, K.M.; Henson, N.; Castillo-Carranza, D.L.; Murillo, M.C.; Sengupta, U.; Barrett, A.; Kayed, R. Tau oligomers mediate $\alpha$-synuclein toxicity and can be targeted by immunotherapy. Mol. Neurodegener. 2018, 13, 1-14. [CrossRef] [PubMed] 
96. Gerson, J.E.; Sengupta, U.; Kayed, R. Tau oligomers as pathogenic seeds: Preparation and propagation in vitro and in vivo. In Tau Protein; Humana Press: New York, NY, USA, 2017; pp. 141-157.

97. Bengoa-Vergniory, N.; Roberts, R.F.; Wade-Martins, R.; Alegre-Abarrategui, J. Alpha-synuclein oligomers: A new hope. Acta Neuropathol. 2017, 134, 819-838. [CrossRef]

98. Gerson, J.E.; Mudher, A.; Kayed, R. Potential mechanisms and implications for the formation of tau oligomeric strains. Crit. Rev. Biochem. Mol. Biol. 2016, 51, 482-496. [CrossRef]

99. Brettschneider, J.; Del Tredici, K.; Lee, V.M.; Trojanowski, J.Q. Spreading of pathology in neurodegenerative diseases: A focus on human studies. Nat. Rev. Neurosci. 2015, 16, 109-120. [CrossRef]

100. Rubinsztein, D.C. The roles of intracellular protein-degradation pathways in neurodegeneration. Nature 2006, $443, \mathbf{7 8 0 - 7 8 6 .}$ [CrossRef]

101. Selkoe, D.J. Folding proteins in fatal ways. Nature 2003, 426, 900-904. [CrossRef]

102. Selkoe, D.J.; Hardy, J. The amyloid hypothesis of Alzheimer's disease at 25 years. EMBO Mol. Med. 2016, 8, 595-608. [CrossRef]

103. Cecarini, V.; Bonfili, L.; Amici, M.; Angeletti, M.; Keller, J.N.; Eleuteri, A.M. Amyloid peptides in different assembly states and related effects on isolated and cellular proteasomes. Brain Res. 2008, 1209, 8-18. [CrossRef]

104. Díaz-Hernández, M.; Valera, A.G.; Morán, M.A.; Gómez-Ramos, P.; Alvarez-Castelao, B.; Castaño, J.G.; Hernández, F.; Lucas, J.J. Inhibition of $26 \mathrm{~S}$ proteasome activity by huntingtin filaments but not inclusion bodies isolated from mouse and human brain. $J$. Neurochem. 2006, 98, 1585-1596. [CrossRef]

105. Gregori, L.; Fuchs, C.; Figueiredo-Pereira, M.E.; Van Nostrand, W.E.; Goldgaber, D. Amyloid $\beta$-Protein Inhibits Ubiquitindependent Protein Degradation in Vitro (*). J. Biol. Chem. 1995, 270, 19702-19708. [CrossRef] [PubMed]

106. Lindersson, E.; Beedholm, R.; Højrup, P.; Moos, T.; Gai, W.; Hendil, K.B.; Jensen, P.H. Proteasomal inhibition by $\alpha$-synuclein filaments and oligomers. J. Biol. Chem. 2004, 279, 12924-12934. [CrossRef] [PubMed]

107. Bence, N.F.; Sampat, R.M.; Kopito, R.R. Impairment of the ubiquitin-proteasome system by protein aggregation. Science 2001, 292, 1552-1555. [CrossRef]

108. Oh, S.; Hong, H.S.; Hwang, E.; Sim, H.J.; Lee, W.; Shin, S.J.; Mook-Jung, I. Amyloid peptide attenuates the proteasome activity in neuronal cells. Mech. Ageing Dev. 2005, 126, 1292-1299. [CrossRef]

109. Tanaka, K.; Matsuda, N. Proteostasis and neurodegeneration: The roles of proteasomal degradation and autophagy. Biochim. Biophys. Acta 2014, 1843, 197-204. [CrossRef]

110. Tanaka, Y.; Engelender, S.; Igarashi, S.; Rao, R.K.; Wanner, T.; Tanzi, R.E.; Sawa, A.; Dawson, V.L.; Dawson, T.M.; Ross, C.A. Inducible expression of mutant $\alpha$-synuclein decreases proteasome activity and increases sensitivity to mitochondria-dependent apoptosis. Hum. Mol. Genet. 2001, 10, 919-926. [CrossRef] [PubMed]

111. Tseng, B.P.; Green, K.N.; Chan, J.L.; Blurton-Jones, M.; LaFerla, F.M. A $\beta$ inhibits the proteasome and enhances amyloid and tau accumulation. Neurobiol. Aging 2008, 29, 1607-1618. [CrossRef] [PubMed]

112. Emmanouilidou, E.; Stefanis, L.; Vekrellis, K. Cell-produced $\alpha$-synuclein oligomers are targeted to, and impair, the $26 \mathrm{~S}$ proteasome. Neurobiol. Aging 2010, 31, 953-968. [CrossRef]

113. Deriziotis, P.; André, R.; Smith, D.M.; Goold, R.; Kinghorn, K.J.; Kristiansen, M.; Nathan, J.A.; Rosenzweig, R.; Krutauz, D.; Glickman, M.H. Misfolded PrP impairs the UPS by interaction with the $20 \mathrm{~S}$ proteasome and inhibition of substrate entry. EMBO J. 2011, 30, 3065-3077. [CrossRef] [PubMed]

114. Deriziotis, P.; Tabrizi, S.J. Prions and the proteasome. Biochim. Biophys. Acta 2008, 1782, 713-722. [CrossRef] [PubMed]

115. Kristiansen, M.; Deriziotis, P.; Dimcheff, D.E.; Jackson, G.S.; Ovaa, H.; Naumann, H.; Clarke, A.R.; van Leeuwen, F.W.; Menéndez-Benito, V.; Dantuma, N.P. Disease-associated prion protein oligomers inhibit the 26S proteasome. Mol. Cell 2007, 26, 175-188. [CrossRef] [PubMed]

116. Thibaudeau, T.A.; Anderson, R.T.; Smith, D.M. A common mechanism of proteasome impairment by neurodegenerative disease-associated oligomers. Nat. Commun. 2018, 9, 1097. [CrossRef]

117. Zondler, L.; Kostka, M.; Garidel, P.; Heinzelmann, U.; Hengerer, B.; Mayer, B.; Weishaupt, J.H.; Gillardon, F.; Danzer, K.M. Proteasome impairment by $\alpha$-synuclein. PLoS ONE 2017, 12, e0184040. [CrossRef] [PubMed]

118. Ruegsegger, C.; Saxena, S. Proteostasis impairment in ALS. Brain Res. 2016, 1648, 571-579. [CrossRef]

119. Myeku, N.; Clelland, C.L.; Emrani, S.; Kukushkin, N.V.; Yu, W.H.; Goldberg, A.L.; Duff, K.E. Tau-driven 26S proteasome impairment and cognitive dysfunction can be prevented early in disease by activating cAMP-PKA signaling. Nat. Med. 2016, 22, 46-53. [CrossRef]

120. Papanikolopoulou, K.; Skoulakis, E. Altered proteostasis in neurodegenerative tauopathies. In Proteostasis and Disease; Barrio, R., Sutherland, J.D., Rodriguez, M.S., Eds.; Springer International Publishing: Cham, Switzerland, 2020; pp. 177-194.

121. Choi, W.H.; De Poot, S.A.; Lee, J.H.; Kim, J.H.; Han, D.H.; Kim, Y.K.; Finley, D.; Lee, M.J. Open-gate mutants of the mammalian proteasome show enhanced ubiquitin-conjugate degradation. Nat. Commun. 2016, 7, 1-12. [CrossRef]

122. Leestemaker, Y.; de Jong, A.; Witting, K.F.; Penning, R.; Schuurman, K.; Rodenko, B.; Zaal, E.A.; van de Kooij, B.; Laufer, S.; Heck, A.J. Proteasome activation by small molecules. Cell Chem. Biol. 2017, 24, 725-736. [CrossRef]

123. Leestemaker, Y.; Ovaa, H. Tools to investigate the ubiquitin proteasome system. Drug Discov. Today Technol. 2017, $26,25-31$. [CrossRef]

124. Lee, B.-H.; Lee, M.J.; Park, S.; Oh, D.-C.; Elsasser, S.; Chen, P.-C.; Gartner, C.; Dimova, N.; Hanna, J.; Gygi, S.P. Enhancement of proteasome activity by a small-molecule inhibitor of USP14. Nature 2010, 467, 179-184. [CrossRef] 
125. Fiolek, T.J.; Magyar, C.L.; Wall, T.J.; Davies, S.B.; Campbell, M.V.; Savich, C.J.; Tepe, J.J.; Mosey, R.A. Dihydroquinazolines enhance $20 \mathrm{~S}$ proteasome activity and induce degradation of alpha-synuclein, an intrinsically disordered protein associated with neurodegeneration. Bioorg. Med. Chem. Lett. 2021, 36, 127821. [CrossRef]

126. Coleman, R.A.; Muli, C.S.; Zhao, Y.; Bhardwaj, A.; Newhouse, T.R.; Trader, D.J. Analysis of chain length, substitution patterns, and unsaturation of AM-404 derivatives as 20S proteasome stimulators. Bioorg. Med. Chem. Lett. 2019, 29, 420-423. [CrossRef] [PubMed]

127. Coleman, R.A.; Trader, D.J. Development and Application of a Sensitive Peptide Reporter to Discover 20S Proteasome Stimulators. ACS Comb. Sci. 2018, 20, 269-276. [CrossRef] [PubMed]

128. Giżynńska, M.; Witkowska, J.; Karpowicz, P.; Rostankowski, R.; Chocron, E.S.; Pickering, A.M.; Osmulski, P.; Gaczynska, M.; Jankowska, E.b. Proline-and arginine-rich peptides as flexible allosteric modulators of human proteasome activity. J. Med. Chem. 2019, 62, 359-370. [CrossRef]

129. Njomen, E.; Lansdell, T.; Vanecek, A.; Benham, V.; Bernard, M.; Yang, Y.-T.; Schall, P.; Isaac, D.; Alkharabsheh, O.; Al-Janadi, A. Enhancing c-MYC degradation via 20S proteasome activation induces in vivo anti-tumor efficacy. bioRxiv 2020. [CrossRef]

130. Chondrogianni, N.; Georgila, K.; Kourtis, N.; Tavernarakis, N.; Gonos, E.S. 20S proteasome activation promotes life span extension and resistance to proteotoxicity in Caenorhabditis elegans. FASEB J. 2015, 29, 611-622. [CrossRef]

131. Gonos, E. Proteasome activation as a novel anti-aging strategy. Free Radic. Biol. Med. 2014, 75, S7. [CrossRef] [PubMed]

132. Fiolek, T.J.; Keel, K.L.; Tepe, J.J. Fluspirilene Analogs Activate the 20 S Proteasome and Overcome Proteasome Impairment by Intrinsically Disordered Protein Oligomers. ACS Chem. Neurosci. 2021, 12, 1438-1448. [CrossRef]

133. Ben-Nissan, G.; Sharon, M. Regulating the $20 \mathrm{~S}$ proteasome ubiquitin-independent degradation pathway. Biomolecules 2014, 4 , 862-884. [CrossRef] [PubMed]

134. Njomen, E.; Tepe, J.J. Regulation of Autophagic Flux by the $20 S$ Proteasome. Cell Chem. Biol. 2019, 26, 1283-1294. [CrossRef] [PubMed]

135. Asher, G.; Reuven, N.; Shaul, Y. 20S proteasomes and protein degradation "by default". Bioessays 2006, 28, 844-849. [CrossRef]

136. Korovila, I.; Hugo, M.; Castro, J.P.; Weber, D.; Höhn, A.; Grune, T.; Jung, T. Proteostasis, oxidative stress and aging. Redox Biol. 2017, 13, 550-567. [CrossRef]

137. Höhn, T.J.; Grune, T. The proteasome and the degradation of oxidized proteins: Part III-Redox regulation of the proteasomal system. Redox Biol. 2014, 2, 388-394. [PubMed]

138. Chondrogianni, N.; Petropoulos, I.; Grimm, S.; Georgila, K.; Catalgol, B.; Friguet, B.; Grune, T.; Gonos, E.S. Protein damage, repair and proteolysis. Mol. Aspects Med. 2014, 35, 1-71. [CrossRef] [PubMed]

139. Myers, N.; Olender, T.; Savidor, A.; Levin, Y.; Reuven, N.; Shaul, Y. The Disordered Landscape of the 20S Proteasome Substrates Reveals Tight Association with Phase Separated Granules. Proteomics 2018, 18, e1800076. [CrossRef]

140. Tsvetkov, P.; Reuven, N.; Shaul, Y. The nanny model for IDPs. Nat. Chem. Biol. 2009, 5, 778-781. [CrossRef]

141. Oliver, C.N.; Ahn, B.W.; Moerman, E.J.; Goldstein, S.; Stadtman, E.R. Age-related changes in oxidized proteins. J. Biol. Chem. 1987, 262, 5488-5491. [CrossRef]

142. Carrard, G.; Dieu, M.; Raes, M.; Toussaint, O.; Friguet, B. Impact of ageing on proteasome structure and function in human lymphocytes. Int. J. Biochem. Cell Biol. 2003, 35, 728-739. [CrossRef]

143. Keller, J.N.; Huang, F.F.; Markesbery, W.R. Decreased levels of proteasome activity and proteasome expression in aging spinal cord. Neuroscience 2000, 98, 149-156. [CrossRef]

144. Giannini, C.; Kloß, A.; Gohlke, S.; Mishto, M.; Nicholson, T.P.; Sheppard, P.W.; Kloetzel, P.M.; Dahlmann, B. Poly-Ub-substratedegradative activity of $26 \mathrm{~S}$ proteasome is not impaired in the aging rat brain. PLoS ONE 2013, 8, e64042. [CrossRef]

145. Merker, K.; Sitte, N.; Grune, T. Hydrogen peroxide-mediated protein oxidation in young and old human MRC-5 fibroblasts. Arch. Biochem. Biophys. 2000, 375, 50-54. [CrossRef] [PubMed]

146. Sitte, N.; Merker, K.; von Zglinicki, T.; Grune, T. Protein oxidation and degradation during proliferative senescence of human MRC-5 fibroblasts. Free Radic. Biol. Med. 2000, 28, 701-708. [CrossRef]

147. Reeg, S.; Grune, T. Protein Oxidation in Aging: Does It Play a Role in Aging Progression? Antioxid. Redox Signal. 2014, 23, 239-255. [CrossRef] [PubMed]

148. Deger, J.M.; Gerson, J.E.; Kayed, R. The interrelationship of proteasome impairment and oligomeric intermediates in neurodegeneration. Aging Cell 2015, 14, 715-724. [CrossRef] [PubMed]

149. McKinnon, C.; Goold, R.; Andre, R.; Devoy, A.; Ortega, Z.; Moonga, J.; Linehan, J.M.; Brandner, S.; Lucas, J.J.; Collinge, J.; et al. Prion-mediated neurodegeneration is associated with early impairment of the ubiquitin-proteasome system. Acta Neuropathol. 2016, 131, 411-425. [CrossRef]

150. Otero, A.; Betancor, M.; Erana, H.; Fernandez Borges, N.; Lucas, J.J.; Badiola, J.J.; Castilla, J.; Bolea, R. Prion-Associated Neurodegeneration Causes Both Endoplasmic Reticulum Stress and Proteasome Impairment in a Murine Model of Spontaneous Disease. Int. J. Mol. Sci. 2021, 22, 465. [CrossRef]

151. Parkinson's Disease Foundation. Available online: https://www.parkinson.org/Understanding-Parkinsons/Statistics (accessed on 17 October 2021).

152. Moore, D.J.; Dawson, V.L.; Dawson, T.M. Role for the ubiquitin-proteasome system in Parkinson's disease and other neurodegenerative brain amyloidoses. Neuromolecular Med. 2003, 4, 95-108. [CrossRef] 
153. McNaught, K.S.P.; Jenner, P. Proteasomal function is impaired in substantia nigra in Parkinson's disease. Neurosci. Lett. 2001, 297, 191-194. [CrossRef]

154. McNaught, K.S.; Perl, D.P.; Brownell, A.L.; Olanow, C.W. Systemic exposure to proteasome inhibitors causes a progressive model of Parkinson's disease. Ann. Neurol. 2004, 56, 149-162. [CrossRef]

155. Matsuda, N.; Tanaka, K. Does Impairment of the Ubiquitin-Proteasome System or the Autophagy-Lysosome Pathway Predispose Individuals to Neurodegenerative Disorders such as Parkinson's Disease? J. Alzheimer's Dis. 2010, 19, 1-9. [CrossRef] [PubMed]

156. Kincaid, E.Z.; Che, J.W.; York, I.; Escobar, H.; Reyes-Vargas, E.; Delgado, J.C.; Welsh, R.M.; Karow, M.L.; Murphy, A.J.; Valenzuela, D.M.; et al. Mice completely lacking immunoproteasomes show major changes in antigen presentation. Nat. Immunol. 2012, 13, 129-135. [CrossRef] [PubMed]

157. Bedford, L.; Hay, D.; Devoy, A.; Paine, S.; Powe, D.G.; Seth, R.; Gray, T.; Topham, I.; Fone, K.; Rezvani, N. Depletion of 26S proteasomes in mouse brain neurons causes neurodegeneration and Lewy-like inclusions resembling human pale bodies. $J$. Neurosci. 2008, 28, 8189-8198. [CrossRef] [PubMed]

158. FastStats-Leading Causes of Death. Available online: https://www.cdc.gov/nchs/fastats/leading-causes-of-death.htm (accessed on 17 October 2021).

159. 2019 Alzheimer's disease facts and figures. Alzheimer's $\mathcal{E}$ Dement. 2019, 15, 321-387.

160. Tiwari, S.; Atluri, V.; Kaushik, A.; Yndart, A.; Nair, M. Alzheimer's disease: Pathogenesis, diagnostics, and therapeutics. Int. J. Nanomed. 2019, 14, 5541-5554. [CrossRef] [PubMed]

161. Goedert, M. Alzheimer's and Parkinson's diseases: The prion concept in relation to assembled A $\beta$, tau, and $\alpha$-synuclein. Science 2015, 349, 1255555. [CrossRef] [PubMed]

162. Ferreira, S.; Lourenco, M.; Oliveira, M.; De Felice, F. Soluble amyloid-b oligomers as synaptotoxins leading to cognitive impairment in Alzheimer's disease. Front. Cell. Neurosci. 2015, 9, 191. [CrossRef]

163. Cleary, J.P.; Walsh, D.M.; Hofmeister, J.J.; Shankar, G.M.; Kuskowski, M.A.; Selkoe, D.J.; Ashe, K.H. Natural oligomers of the amyloid- $\beta$ protein specifically disrupt cognitive function. Nat. Neurosci. 2005, 8, 79-84. [CrossRef] [PubMed]

164. Balducci, C.; Beeg, M.; Stravalaci, M.; Bastone, A.; Sclip, A.; Biasini, E.; Tapella, L.; Colombo, L.; Manzoni, C.; Borsello, T. Synthetic amyloid- $\beta$ oligomers impair long-term memory independently of cellular prion protein. Proc. Natl. Acad. Sci. USA 2010, 107, 2295-2300. [CrossRef]

165. Shankar, G.M.; Li, S.; Mehta, T.H.; Garcia-Munoz, A.; Shepardson, N.E.; Smith, I.; Brett, F.M.; Farrell, M.A.; Rowan, M.J.; Lemere, C.A. Amyloid- $\beta$ protein dimers isolated directly from Alzheimer's brains impair synaptic plasticity and memory. Nat. Med. 2008, 14, 837-842. [CrossRef]

166. Lopez Salon, M.; Pasquini, L.; Besio Moreno, M.; Pasquini, J.M.; Soto, E. Relationship between beta-amyloid degradation and the 26S proteasome in neural cells. Exp. Neurol. 2003, 180, 131-143. [CrossRef]

167. Hong, L.; Huang, H.C.; Jiang, Z.F. Relationship between amyloid-beta and the ubiquitin-proteasome system in Alzheimer's disease. Neurol. Res. 2014, 36, 276-282. [CrossRef] [PubMed]

168. Wang, H.; Saunders, A.J. The role of ubiquitin-proteasome in the metabolism of amyloid precursor protein (APP): Implications for novel therapeutic strategies for Alzheimer's disease. Discov. Med. 2014, 18, 41-50. [PubMed]

169. Riederer, B.M.; Leuba, G.; Vernay, A.; Riederer, I.M. The role of the ubiquitin proteasome system in Alzheimer's disease. Exp. Biol. Med. 2011, 236, 268-276. [CrossRef]

170. Vonsattel, J.P.; DiFiglia, M. Huntington disease. J. Neuropathol. Exp. Neurol. 1998, 57, 369-384. [CrossRef] [PubMed]

171. Sánchez, I.; Mahlke, C.; Yuan, J. Pivotal role of oligomerization in expanded polyglutamine neurodegenerative disorders. Nature 2003, 421, 373-379. [CrossRef] [PubMed]

172. Snell, R.G.; MacMillan, J.C.; Cheadle, J.P.; Fenton, I.; Lazarou, L.P.; Davies, P.; MacDonald, M.E.; Gusella, J.F.; Harper, P.S.; Shaw, D.J. Relationship between trinucleotide repeat expansion and phenotypic variation in Huntington's disease. Nat. Genet. 1993, 4, 393-397. [CrossRef]

173. Nance, M.A.; Myers, R.H. Juvenile onset Huntington's disease-clinical and research perspectives. Ment. Retard. Dev. Disabil. Res. Rev. 2001, 7, 153-157. [CrossRef]

174. Dantuma, N.P.; Bott, L.C. The ubiquitin-proteasome system in neurodegenerative diseases: Precipitating factor, yet part of the solution. Front. Mol. Neurosci. 2014, 7, 70. [CrossRef]

175. Hipp, M.S.; Patel, C.N.; Bersuker, K.; Riley, B.E.; Kaiser, S.E.; Shaler, T.A.; Brandeis, M.; Kopito, R.R. Indirect inhibition of $26 \mathrm{~S}$ proteasome activity in a cellular model of Huntington's disease. J. Cell Biol. 2012, 196, 573-587. [CrossRef]

176. Kalchman, M.A.; Graham, R.K.; Xia, G.; Koide, H.B.; Hodgson, J.G.; Graham, K.C.; Goldberg, Y.P.; Gietz, R.D.; Pickart, C.M.; Hayden, M.R. Huntingtin is ubiquitinated and interacts with a specific ubiquitin-conjugating enzyme. J. Biol. Chem. 1996, 271, 19385-19394. [CrossRef]

177. Seo, H.; Sonntag, K.C.; Kim, W.; Cattaneo, E.; Isacson, O. Proteasome activator enhances survival of Huntington's disease neuronal model cells. PLoS One 2007, 2, e238. [CrossRef]

178. Taylor, J.P.; Brown, R.H.; Cleveland, D.W. Decoding ALS: From genes to mechanism. Nature 2016, 539, 197-206. [CrossRef]

179. Al-Chalabi, A.; Hardiman, O. The epidemiology of ALS: A conspiracy of genes, environment and time. Nat. Rev. Neurol. 2013, 9 , 617-628. [CrossRef]

180. Turner, M.R.; Hardiman, O.; Benatar, M.; Brooks, B.R.; Chio, A.; de Carvalho, M.; Ince, P.G.; Lin, C.; Miller, R.G.; Mitsumoto, H.; et al. Controversies and priorities in amyotrophic lateral sclerosis. Lancet Neurol. 2013, 12, 310-322. [CrossRef] 
181. Rosen, D.R.; Siddique, T.; Patterson, D.; Figlewicz, D.A.; Sapp, P.; Hentati, A.; Donaldson, D.; Goto, J.; O'Regan, J.P.; Deng, H.X.; et al. Mutations in $\mathrm{Cu} / \mathrm{Zn}$ superoxide dismutase gene are associated with familial amyotrophic lateral sclerosis. Nature 1993, 362, 59-62. [CrossRef]

182. Sreedharan, J.; Blair, I.P.; Tripathi, V.B.; Hu, X.; Vance, C.; Rogelj, B.; Ackerley, S.; Durnall, J.C.; Williams, K.L.; Buratti, E.; et al. TDP-43 mutations in familial and sporadic amyotrophic lateral sclerosis. Science 2008, 319, 1668-1672. [CrossRef]

183. Vance, C.; Rogelj, B.; Hortobágyi, T.; De Vos, K.J.; Nishimura, A.L.; Sreedharan, J.; Hu, X.; Smith, B.; Ruddy, D.; Wright, P.; et al. Mutations in FUS, an RNA processing protein, cause familial amyotrophic lateral sclerosis type 6. Science 2009, 323, $1208-1211$. [CrossRef]

184. Deng, H.X.; Chen, W.; Hong, S.T.; Boycott, K.M.; Gorrie, G.H.; Siddique, N.; Yang, Y.; Fecto, F.; Shi, Y.; Zhai, H.; et al. Mutations in UBQLN2 cause dominant X-linked juvenile and adult-onset ALS and ALS/dementia. Nature 2011, 477, 211-215. [CrossRef]

185. DeJesus-Hernandez, M.; Mackenzie, I.R.; Boeve, B.F.; Boxer, A.L.; Baker, M.; Rutherford, N.J.; Nicholson, A.M.; Finch, N.A.; Flynn, H.; Adamson, J.; et al. Expanded GGGGCC hexanucleotide repeat in noncoding region of C9ORF72 causes chromosome 9p-linked FTD and ALS. Neuron 2011, 72, 245-256. [CrossRef]

186. Renton, A.E.; Majounie, E.; Waite, A.; Simón-Sánchez, J.; Rollinson, S.; Gibbs, J.R.; Schymick, J.C.; Laaksovirta, H.; van Swieten, J.C.; Myllykangas, L.; et al. A hexanucleotide repeat expansion in C9ORF72 is the cause of chromosome 9p21-linked ALS-FTD. Neuron 2011, 72, 257-268. [CrossRef]

187. Peter, E.A.A.; Bieniek, K.F.; Gendron, T.F.; Caulfield, T.; Lin, W.-L.; DeJesus-Hernandez, M.; van Blitterswijk, M.M.; Jansen-West, K.; Paul, J.W.; Rademakers, R.; et al. Unconventional Translation of C9ORF72 GGGGCC Expansion Generates Insoluble Polypeptides Specific to c9FTD/ALS. Neuron 2013, 77, 639-646.

188. Gendron, T.F.; Bieniek, K.F.; Zhang, Y.-J.; Jansen-West, K.; Ash, P.E.A.; Caulfield, T.; Daughrity, L.; Dunmore, J.H.; Castanedes-Casey, M.; Chew, J.; et al. Antisense transcripts of the expanded C9ORF72 hexanucleotide repeat form nuclear RNA foci and undergo repeat-associated non-ATG translation in c9FTD/ALS. Acta Neuropathol. 2013, 126, 829-844. [CrossRef] [PubMed]

189. Mori, K.; Arzberger, T.; Grässer, F.A.; Gijselinck, I.; May, S.; Rentzsch, K.; Weng, S.-M.; Schludi, M.H.; van der Zee, J.; Cruts, M.; et al. Bidirectional transcripts of the expanded C9orf72 hexanucleotide repeat are translated into aggregating dipeptide repeat proteins. Acta Neuropathol. 2013, 126, 881-893. [CrossRef] [PubMed]

190. Mori, K.; Weng, S.-M.; Arzberger, T.; May, S.; Rentzsch, K.; Kremmer, E.; Schmid, B.; Kretzschmar Hans, A.; Cruts, M.; Van Broeckhoven, C.; et al. The C9orf72 GGGGCC Repeat Is Translated into Aggregating Dipeptide-Repeat Proteins in FTLD/ALS. Science 2013, 339, 1335-1338. [CrossRef] [PubMed]

191. Zu, T.; Liu, Y.; Bañez-Coronel, M.; Reid, T.; Pletnikova, O.; Lewis, J.; Miller, T.M.; Harms, M.B.; Falchook, A.E.; Subramony, S.H.; et al. RAN proteins and RNA foci from antisense transcripts in C9ORF72 ALS and frontotemporal dementia. Proc. Natl. Acad. Sci. USA 2013, 110, E4968. [CrossRef] [PubMed]

192. Guo, Q.; Lehmer, C.; Martínez-Sánchez, A.; Rudack, T.; Beck, F.; Hartmann, H.; Pérez-Berlanga, M.; Frottin, F.; Hipp, M.S.; Hartl, F.U.; et al. In Situ Structure of Neuronal C9orf72 Poly-GA Aggregates Reveals Proteasome Recruitment. Cell 2018, 172, 696-705.e612. [CrossRef]

193. Kato, S. Amyotrophic lateral sclerosis models and human neuropathology: Similarities and differences. Acta Neuropathol. 2008, 115, 97-114. [CrossRef]

194. Strong, M.J.; Kesavapany, S.; Pant, H.C. The Pathobiology of Amyotrophic Lateral Sclerosis: A Proteinopathy? J. Neuropathol. Exp. Neurol. 2005, 64, 649-664. [CrossRef]

195. Bendotti, C.; Atzori, C.; Piva, R.; Tortarolo, M.; Strong, M.J.; Debiasi, S.; Migheli, A. Activated p38MAPK is a novel component of the intracellular inclusions found in human amyotrophic lateral sclerosis and mutant SOD1 transgenic mice. J. Neuropathol. Exp. Neurol. 2004, 63, 113-119. [CrossRef]

196. Leigh, P.N.; Whitwell, H.; Garofalo, O.; Buller, J.; Swash, M.; Martin, J.E.; Gallo, J.M.; Weller, R.O.; Anderton, B.H. Ubiquitinimmunoreactive intraneuronal inclusions in amyotrophic lateral sclerosis. Morphology, distribution, and specificity. Brain 1991, 114, 775-788. [CrossRef] [PubMed]

197. Bendotti, C.; Marino, M.; Cheroni, C.; Fontana, E.; Crippa, V.; Poletti, A.; De Biasi, S. Dysfunction of constitutive and inducible ubiquitin-proteasome system in amyotrophic lateral sclerosis: Implication for protein aggregation and immune response. Prog. Neurobiol. 2012, 97, 101-126. [CrossRef] [PubMed]

198. Goldberg, A.L.; Kim, H.T.; Lee, D.; Collins, G.A. Mechanisms That Activate 26S Proteasomes and Enhance Protein Degradation. Biomolecules 2021, 11, 779. [CrossRef] [PubMed]

199. Verma, R.; Aravind, L.; Oania, R.; McDonald, W.H.; Yates, J.R., 3rd; Koonin, E.V.; Deshaies, R.J. Role of Rpn11 metalloprotease in deubiquitination and degradation by the 26S proteasome. Science 2002, 298, 611-615. [CrossRef] [PubMed]

200. Shin, J.Y.; Muniyappan, S.; Tran, N.N.; Park, H.; Lee, S.B.; Lee, B.H. Deubiquitination Reactions on the Proteasome for Proteasome Versatility. Int. J. Mol. Sci. 2020, 21, 5312. [CrossRef]

201. Finley, D. Recognition and Processing of Ubiquitin-Protein Conjugates by the Proteasome. Annu. Rev. Biochem 2009, 78, 477-513. [CrossRef] [PubMed]

202. Yao, T.; Cohen, R.E. A cryptic protease couples deubiquitination and degradation by the proteasome. Nature 2002, $419,403-407$. [CrossRef] 
203. Nijman, S.M.; Luna-Vargas, M.P.; Velds, A.; Brummelkamp, T.R.; Dirac, A.M.; Sixma, T.K.; Bernards, R. A genomic and functional inventory of deubiquitinating enzymes. Cell 2005, 123, 773-786. [CrossRef]

204. Lee, M.J.; Lee, B.H.; Hanna, J.; King, R.W.; Finley, D. Trimming of ubiquitin chains by proteasome-associated deubiquitinating enzymes. Mol. Cell. Proteomics 2011, 10, R110.003871. [CrossRef]

205. Koulich, E.; Li, X.; DeMartino, G.N. Relative structural and functional roles of multiple deubiquitylating proteins associated with mammalian 26S proteasome. Mol. Biol. Cell 2008, 19, 1072-1082. [CrossRef]

206. Kim, H.T.; Goldberg, A.L. The deubiquitinating enzyme Usp14 allosterically inhibits multiple proteasomal activities and ubiquitin-independent proteolysis. J. Biol. Chem. 2017, 292, 9830-9839. [CrossRef] [PubMed]

207. Aufderheide, A.; Beck, F.; Stengel, F.; Hartwig, M.; Schweitzer, A.; Pfeifer, G.; Goldberg, A.L.; Sakata, E.; Baumeister, W.; Förster, F. Structural characterization of the interaction of Ubp6 with the 26S proteasome. Proc Natl Acad Sci USA 2015, 112, 8626-8631. [CrossRef] [PubMed]

208. Kuo, C.L.; Goldberg, A.L. Ubiquitinated proteins promote the association of proteasomes with the deubiquitinating enzyme Usp14 and the ubiquitin ligase Ube3c. Proc. Natl. Acad. Sci. USA 2017, 114, E3404-e3413. [CrossRef] [PubMed]

209. Lee, B.H.; Lu, Y.; Prado, M.A.; Shi, Y.; Tian, G.; Sun, S.; Elsasser, S.; Gygi, S.P.; King, R.W.; Finley, D. USP14 deubiquitinates proteasome-bound substrates that are ubiquitinated at multiple sites. Nature 2016, 532, 398-401. [CrossRef] [PubMed]

210. Moon, S.; Muniyappan, S.; Lee, S.-B.; Lee, B.-H. Small-Molecule Inhibitors Targeting Proteasome-Associated Deubiquitinases. Int. J. Mol. Sci. 2021, 22, 6213. [CrossRef]

211. Lam, Y.A.; Xu, W.; DeMartino, G.N.; Cohen, R.E. Editing of ubiquitin conjugates by an isopeptidase in the $26 \mathrm{~S}$ proteasome. Nature 1997, 385, 737-740. [CrossRef]

212. Deol, K.K.; Crowe, S.O.; Du, J.; Bisbee, H.; Guenette, R.G.; Strieter, E.R. Proteasome-Bound UCH37 Debranches Ubiquitin Chains to Promote Degradation. Mol. Cell 2020, 80, 796-809. [CrossRef]

213. Boselli, M.; Lee, B.H.; Robert, J.; Prado, M.A.; Min, S.W.; Cheng, C.; Silva, M.C.; Seong, C.; Elsasser, S.; Hatle, K.M.; et al. An inhibitor of the proteasomal deubiquitinating enzyme USP14 induces tau elimination in cultured neurons. J. Biol. Chem. 2017, 292, 19209-19225. [CrossRef] [PubMed]

214. Wang, Y.; Jiang, Y.; Ding, S.; Li, J.; Song, N.; Ren, Y.; Hong, D.; Wu, C.; Li, B.; Wang, F.; et al. Small molecule inhibitors reveal allosteric regulation of USP14 via steric blockade. Cell Res. 2018, 28, 1186-1194. [CrossRef]

215. Palmer, A.L.; de Jong, A.; Leestemaker, Y.; Geurink, P.P.; Wijdeven, R.H.; Ovaa, H.; Dolan, B.P. Inhibition of the deubiquitinase Usp14 diminishes direct MHC class I antigen presentation. J. Immunol. 2018, 200, 928-936. [CrossRef] [PubMed]

216. Kim, E.; Park, S.; Lee, J.H.; Mun, J.Y.; Choi, W.H.; Yun, Y.; Lee, J.; Kim, J.H.; Kang, M.J.; Lee, M.J. Dual Function of USP14 Deubiquitinase in Cellular Proteasomal Activity and Autophagic Flux. Cell Rep. 2018, 24, 732-743. [CrossRef]

217. VerPlank, J.J.; Goldberg, A.L. Regulating protein breakdown through proteasome phosphorylation. Biochem. J. 2017, 474, 3355-3371. [CrossRef] [PubMed]

218. Zhang, F.; Hu, Y.; Huang, P.; Toleman, C.A.; Paterson, A.J.; Kudlow, J.E. Proteasome function is regulated by cyclic AMPdependent protein kinase through phosphorylation of Rpt6. J. Biol. Chem. 2007, 282, 22460-22471. [CrossRef] [PubMed]

219. Asai, M.; Tsukamoto, O.; Minamino, T.; Asanuma, H.; Fujita, M.; Asano, Y.; Takahama, H.; Sasaki, H.; Higo, S.; Asakura, M.; et al. PKA rapidly enhances proteasome assembly and activity in in vivo canine hearts. J. Mol. Cell. Cardiol. 2009, 46, 452-462. [CrossRef] [PubMed]

220. Lokireddy, S.; Kukushkin, N.V.; Goldberg, A.L. cAMP-induced phosphorylation of 26S proteasomes on Rpn6/PSMD11 enhances their activity and the degradation of misfolded proteins. Proc. Natl. Acad. Sci. USA 2015, 112, E7176-E7185. [CrossRef]

221. VerPlank, J.J.; Lokireddy, S.; Zhao, J.; Goldberg, A.L. 26S Proteasomes are rapidly activated by diverse hormones and physiological states that raise cAMP and cause Rpn6 phosphorylation. Proc. Natl. Acad. Sci. USA 2019, 116, 4228-4237. [CrossRef]

222. Banerjee, S.; Ji, C.; Mayfield, J.E.; Goel, A.; Xiao, J.; Dixon, J.E.; Guo, X. Ancient drug curcumin impedes $26 \mathrm{~S}$ proteasome activity by direct inhibition of dual-specificity tyrosine-regulated kinase 2. Proc. Natl. Acad. Sci. USA 2018, 115, 8155. [CrossRef]

223. Guo, X.; Wang, X.; Wang, Z.; Banerjee, S.; Yang, J.; Huang, L.; Dixon, J.E. Site-specific proteasome phosphorylation controls cell proliferation and tumorigenesis. Nat. Cell Biol. 2016, 18, 202-212. [CrossRef]

224. Djakovic, S.N.; Schwarz, L.A.; Barylko, B.; DeMartino, G.N.; Patrick, G.N. Regulation of the Proteasome by Neuronal Activity and Calcium/Calmodulin-dependent Protein Kinase II*. J. Biol. Chem. 2009, 284, 26655-26665. [CrossRef]

225. Djakovic, S.N.; Marquez-Lona, E.M.; Jakawich, S.K.; Wright, R.; Chu, C.; Sutton, M.A.; Patrick, G.N. Phosphorylation of Rpt6 Regulates Synaptic Strength in Hippocampal Neurons. J. Neurosci. 2012, 32, 5126. [CrossRef]

226. Schaler, A.W.; Myeku, N. Cilostazol, a phosphodiesterase 3 inhibitor, activates proteasome-mediated proteolysis and attenuates tauopathy and cognitive decline. Transl. Res. 2018, 193, 31-41. [CrossRef]

227. Zhu, J.; Mix, E.; Winblad, B. The antidepressant and antiinflammatory effects of rolipram in the central nervous system. CNS Drug Rev. 2001, 7, 387-398. [CrossRef]

228. ASHP. Cilostazol Monographs for Professionals. Available online: https://www.drugs.com/monograph/cilostazol.html (accessed on 4 August 2021).

229. A Trial of Cilostazol in Patients with Mild Cognitive Impairment (COMCID). Available online: https://clinicaltrials.gov/ct2 / show / NCT02491268 (accessed on 4 August 2021). 
230. VerPlank, J.J.S.; Tyrkalska, S.D.; Fleming, A.; Rubinsztein, D.C.; Goldberg, A.L. cGMP via PKG activates $26 \mathrm{~S}$ proteasomes and enhances degradation of proteins, including ones that cause neurodegenerative diseases. Proc. Natl. Acad. Sci. USA 2020, 117, 14220. [CrossRef] [PubMed]

231. Yokota, T.; Wang, Y. p38 MAP kinases in the heart. Gene 2016, 575, 369-376. [CrossRef] [PubMed]

232. Li, H.N.; Yang, Q.Q.; Wang, W.T.; Tian, X.; Feng, F.; Zhang, S.T.; Xia, Y.T.; Wang, J.X.; Zou, Y.W.; Wang, J.Y.; et al. Red nucleus IL-33 facilitates the early development of mononeuropathic pain in male rats by inducing TNF-alpha through activating ERK, p38 MAPK, and JAK2/STAT3. J. Neuroinflammation 2021, 18, 150. [CrossRef]

233. Lee, S.-H.; Park, Y.; Yoon, S.K.; Yoon, J.-B. Osmotic Stress Inhibits Proteasome by p38 MAPK-dependent Phosphorylation*. J. Biol. Chem. 2010, 285, 41280-41289. [CrossRef]

234. Zhu, X.; Rottkamp, C.A.; Boux, H.; Takeda, A.; Perry, G.; Smith, M.A. Activation of p38 kinase links tau phosphorylation, oxidative stress, and cell cycle-related events in Alzheimer disease. J. Neuropathol. Exp. Neurol. 2000, 59, 880-888. [CrossRef] [PubMed]

235. Atzori, C.; Ghetti, B.; Piva, R.; Srinivasan, A.N.; Zolo, P.; Delisle, M.B.; Mirra, S.S.; Migheli, A. Activation of the JNK/p38 pathway occurs in diseases characterized by tau protein pathology and is related to tau phosphorylation but not to apoptosis. J. Neuropathol. Exp. Neurol. 2001, 60, 1190-1197. [CrossRef]

236. Tortarolo, M.; Veglianese, P.; Calvaresi, N.; Botturi, A.; Rossi, C.; Giorgini, A.; Migheli, A.; Bendotti, C. Persistent activation of p38 mitogen-activated protein kinase in a mouse model of familial amyotrophic lateral sclerosis correlates with disease progression. Mol. Cell. Neurosci. 2003, 23, 180-192. [CrossRef]

237. Munoz, L.; Ammit, A.J. Targeting p38 MAPK pathway for the treatment of Alzheimer's disease. Neuropharmacology 2010, 58, 561-568. [CrossRef]

238. Huang, Z.-N.; Chen, J.-M.; Huang, L.-C.; Fang, Y.-H.; Her, L.-S. Inhibition of p38 Mitogen-Activated Protein Kinase Ameliorates HAP40 Depletion-Induced Toxicity and Proteasomal Defect in Huntington's Disease Model. Mol. Neurobiol. 2021, 58, $2704-2723$. [CrossRef] [PubMed]

239. Gaczynska, M.; Rock, K.L.; Spies, T.; Goldberg, A.L. Peptidase activities of proteasomes are differentially regulated by the major histocompatibility complex-encoded genes for LMP2 and LMP7. Proc. Natl. Acad. Sci. USA 1994, 91, 9213-9217. [CrossRef]

240. Gaczynska, M.; Goldberg, A.L.; Tanaka, K.; Hendil, K.B.; Rock, K.L. Proteasome subunits X and Y alter peptidase activities in opposite ways to the interferon-gamma-induced subunits LMP2 and LMP7. J. Biol. Chem. 1996, 271, 17275-17280. [CrossRef] [PubMed]

241. Chondrogianni, N.; Tzavelas, C.; Pemberton, A.J.; Nezis, I.P.; Rivett, A.J.; Gonos, E.S. Overexpression of proteasome beta5 assembled subunit increases the amount of proteasome and confers ameliorated response to oxidative stress and higher survival rates. J. Biol. Chem. 2005, 280, 11840-11850. [CrossRef] [PubMed]

242. Vilchez, D.; Boyer, L.; Morantte, I.; Lutz, M.; Merkwirth, C.; Joyce, D.; Spencer, B.; Page, L.; Masliah, E.; Berggren, W.T.; et al. Increased proteasome activity in human embryonic stem cells is regulated by PSMD11. Nature 2012, 489, 304-308. [CrossRef]

243. Kapeta, S.; Chondrogianni, N.; Gonos, E.S. Nuclear erythroid factor 2-mediated proteasome activation delays senescence in human fibroblasts. J. Biol. Chem. 2010, 285, 8171-8184. [CrossRef]

244. Kwak, M.-K.; Wakabayashi, N.; Greenlaw Jennifer, L.; Yamamoto, M.; Kensler Thomas, W. Antioxidants Enhance Mammalian Proteasome Expression through the Keap1-Nrf2 Signaling Pathway. Mol. Cell. Biol. 2003, 23, 8786-8794. [CrossRef] [PubMed]

245. Yueh, M.F.; Tukey, R.H. Nrf2-Keap1 signaling pathway regulates human UGT1A1 expression in vitro and in transgenic UGT1 mice. J. Biol. Chem. 2007, 282, 8749-8758. [CrossRef]

246. Hayes, J.D.; Chanas, S.A.; Henderson, C.J.; McMahon, M.; Sun, C.; Moffat, G.J.; Wolf, C.R.; Yamamoto, M. The Nrf2 transcription factor contributes both to the basal expression of glutathione S-transferases in mouse liver and to their induction by the chemopreventive synthetic antioxidants, butylated hydroxyanisole and ethoxyquin. Biochem. Soc. Trans. 2000, $28,33-41$. [CrossRef]

247. Venugopal, R.; Jaiswal, A.K. Nrf1 and Nrf2 positively and c-Fos and Fra1 negatively regulate the human antioxidant response element-mediated expression of NAD(P)H:quinone oxidoreductase ${ }_{1}$ gene. Proc. Natl. Acad. Sci. USA 1996, 93, 14960.

248. Jang, J.; Wang, Y.; Kim, H.S.; Lalli, M.A.; Kosik, K.S. Nrf2, a regulator of the proteasome, controls self-renewal and pluripotency in human embryonic stem cells. Stem Cells 2014, 32, 2616-2625. [CrossRef]

249. Kwak, M.K.; Cho, J.M.; Huang, B.; Shin, S.; Kensler, T.W. Role of increased expression of the proteasome in the protective effects of sulforaphane against hydrogen peroxide-mediated cytotoxicity in murine neuroblastoma cells. Free Radic. Biol. Med. 2007, 43, 809-817. [CrossRef] [PubMed]

250. Tanaka, K.; Yoshimura, T.; Kumatori, A.; Ichihara, A.; Ikai, A.; Nishigai, M.; Kameyama, K.; Takagi, T. Proteasomes (multi-protease complexes) as $20 \mathrm{~S}$ ring-shaped particles in a variety of eukaryotic cells. J. Biol. Chem. 1988, 263, 16209-16217. [CrossRef]

251. Tanaka, K.; Yoshimura, T.; Ichihara, A. Role of substrate in reversible activation of proteasomes (multi-protease complexes) by sodium dodecyl sulfate. J. Biochem. 1989, 106, 495-500. [CrossRef] [PubMed]

252. Huang, L.; Ho, P.; Chen, C.H. Activation and inhibition of the proteasome by betulinic acid and its derivatives. FEBS Lett. 2007, 581, 4955-4959. [CrossRef] [PubMed]

253. Katsiki, M.; Chondrogianni, N.; Chinou, I.; Rivett, A.J.; Gonos, E.S. The olive constituent oleuropein exhibits proteasome stimulatory properties in vitro and confers life span extension of human embryonic fibroblasts. Rejuvenation Res. 2007, 10, 157-172. [CrossRef] 
254. Tan, Y.; Yu, R.; Pezzuto, J.M. Betulinic Acid-induced Programmed Cell Death in Human Melanoma Cells Involves Mitogenactivated Protein Kinase Activation. Clin. Cancer Res. 2003, 9, 2866-2875. [PubMed]

255. Ruiz de Mena, I.; Mahillo, E.; Arribas, J.; Castaño, J.G. Kinetic mechanism of activation by cardiolipin (diphosphatidylglycerol) of the rat liver multicatalytic proteinase. Biochem. J 1993, 296 (Pt 1), 93-97. [CrossRef]

256. Watanabe, N.; Yamada, S. Activation of 20 S proteasomes from spinach leaves by fatty acids. Plant Cell Physiol. 1996, 37, 147-151. [CrossRef]

257. Liu, H.; Du, D.-M. Recent Advances in the Synthesis of 2-Imidazolines and Their Applications in Homogeneous Catalysis. Adv. Synth. Catal. 2009, 351, 489-519. [CrossRef]

258. Mehedi, M.S.A.; Tepe, J.J. Recent Advances in the Synthesis of Imidazolines (2009-2020). Adv. Synth. Catal. 2020, 362, 4189-4225. [CrossRef]

259. Sharma, V.; Peddibhotla, S.; Tepe, J.J. Sensitization of Cancer Cells to DNA Damaging Agents by Imidazolines. J. Am. Chem. Soc. 2006, 128, 9137-9143. [CrossRef]

260. Kahlon, D.K.; Lansdell, T.A.; Fisk, J.S.; Hupp, C.D.; Friebe, T.L.; Hovde, S.; Jones, A.D.; Dyer, R.D.; Henry, R.W.; Tepe, J.J. Nuclear Factor-kB Mediated Inhibition of Cytokine Production by Imidazoline Scaffolds. J. Med. Chem. 2009, 52, 1302-1309. [CrossRef] [PubMed]

261. Kahlon, D.K.; Lansdell, T.A.; Fisk, J.S.; Tepe, J.J. Structural-activity relationship study of highly-functionalized imidazolines as potent inhibitors of nuclear transcription factor- $\mathrm{kB}$ mediated IL-6 production. Biorg. Med. Chem. 2009, 17, 3093-3103. [CrossRef] [PubMed]

262. Sztanke, K.; Pasternak, K.; Sidor-Wójtowicz, A.; Truchlińska, J.; Jóźwiak, K. Synthesis of imidazoline and imidazo[2,1c] $[1,2,4]$ triazole aryl derivatives containing the methylthio group as possible antibacterial agents. Biorg. Med. Chem. 2006, 14, 3635-3642. [CrossRef]

263. Sharma, V.; Lansdell, T.A.; Peddibhotla, S.; Tepe, J.J. Sensitization of Tumor Cells toward Chemotherapy: Enhancing the Efficacy of Camptothecin with Imidazolines. Chem. Biol. 2004, 11, 1689-1699. [CrossRef] [PubMed]

264. Brewer, M.D.; Dorgan, R.J.J.; Manger, B.R.; Mamalis, P.; Webster, R.A.B. Isothiourea derivatives of 6-phenyl-2,3,5,6tetrahydroimidazo[2,1-b]thiazole with broad-spectrum anthelmintic activity. J. Med. Chem. 1987, 30, 1848-1853. [CrossRef]

265. Crane, L.; Anastassiadou, M.; Hage, S.E.; Stigliani, J.L.; Baziard-Mouysset, G.; Payard, M.; Leger, J.M.; Bizot-Espiard, J.-G.; Ktorza, A.; Caignard, D.-H.; et al. Design and synthesis of novel imidazoline derivatives with potent antihyperglycemic activity in a rat model of type 2 diabetes. Biorg. Med. Chem. 2006, 14, 7419-7433. [CrossRef]

266. Szabo, B. Imidazoline antihypertensive drugs: A critical review on their mechanism of action. Pharmacol. Ther. 2002, 93, 1-35. [CrossRef]

267. Savelyeva, M.V.; Baldenkov, G.N.; Kaverina, N.V. Receptor binding potencies of chlorpromazine, trifluoperazine, fluphenazine and their 10-N-substituted analogues. Biomed. Biochim. Acta 1988, 47, 1085-1087.

268. Medina, D.X.; Caccamo, A.; Oddo, S. Methylene blue reduces a $\beta$ levels and rescues early cognitive deficit by increasing proteasome activity. Brain Pathol. 2011, 21, 140-149. [CrossRef] [PubMed]

269. Zhou, L.; Flores, J.; Noël, A.; Beauchet, O.; Sjöström, P.J.; LeBlanc, A.C. Methylene blue inhibits Caspase- 6 activity, and reverses Caspase-6-induced cognitive impairment and neuroinflammation in aged mice. Acta Neuropathol. Commun. 2019, 7, 210. [CrossRef]

270. Li, W.-J.; Li, Q.; Liu, D.-L.; Ding, M.-W. Synthesis, fungicidal activity, and sterol 14 $\alpha$-demethylase binding interaction of 2-azolyl-3, 4-dihydroquinazolines on Penicillium digitatum. J. Agric. Food Chem. 2013, 61, 1419-1426. [CrossRef] [PubMed]

271. Patterson, S.; Alphey, M.S.; Jones, D.C.; Shanks, E.J.; Street, I.P.; Frearson, J.A.; Wyatt, P.G.; Gilbert, I.H.; Fairlamb, A.H. Dihydroquinazolines as a novel class of Trypanosoma brucei trypanothione reductase inhibitors: Discovery, synthesis, and characterization of their binding mode by protein crystallography. J. Med. Chem. 2011, 54, 6514-6530. [CrossRef]

272. Lee, J.Y.; Park, S.J.; Park, S.J.; Lee, M.J.; Rhim, H.; Seo, S.H.; Kim, K.-S. Growth inhibition of human cancer cells in vitro by T-type calcium channel blockers. Bioorg. Med. Chem. Lett. 2006, 16, 5014-5017. [CrossRef] [PubMed]

273. Heo, J.H.; Seo, H.N.; Choe, Y.J.; Kim, S.; Oh, C.R.; Kim, Y.D.; Rhim, H.; Choo, D.J.; Kim, J.; Lee, J.Y. T-type Ca2+ channel blockers suppress the growth of human cancer cells. Bioorg. Med. Chem. Lett. 2008, 18, 3899-3901. [CrossRef]

274. Al-Obaid, A.M.; Abdel-Hamide, S.G.; El-Kashef, H.A.; Alaa, A.-M.; El-Azab, A.S.; Al-Khamees, H.A.; El-Subbagh, H.I. Substituted quinazolines, part 3. Synthesis, in vitro antitumor activity and molecular modeling study of certain 2-thieno-4 (3H)-quinazolinone analogs. Eur. J. Med. Chem. 2009, 44, 2379-2391. [CrossRef]

275. Jung, S.Y.; Lee, S.H.; Kang, H.B.; Park, H.A.; Chang, S.K.; Kim, J.; Choo, D.J.; Oh, C.R.; Kim, Y.D.; Seo, J.H. Antitumor activity of 3 , 4-dihydroquinazoline dihydrochloride in A549 xenograft nude mice. Bioorg. Med. Chem. Lett. 2010, 20, 6633-6636. [CrossRef]

276. Kang, H.B.; Rim, H.-K.; Park, J.Y.; Choi, H.W.; Choi, D.L.; Seo, J.-H.; Chung, K.-S.; Huh, G.; Kim, J.; Choo, D.J. In vivo evaluation of oral anti-tumoral effect of 3, 4-dihydroquinazoline derivative on solid tumor. Bioorg. Med. Chem. Lett. 2012, 22, 1198-1201. [CrossRef]

277. Rim, H.-K.; Lee, H.-W.; Choi, I.S.; Park, J.Y.; Choi, H.W.; Choi, J.-H.; Cho, Y.-W.; Lee, J.Y.; Lee, K.-T. T-type Ca2+ channel blocker, KYS05047 induces G1 phase cell cycle arrest by decreasing intracellular Ca2+ levels in human lung adenocarcinoma A549 cells. Bioorg. Med. Chem. Lett. 2012, 22, 7123-7126. [CrossRef] 
278. Jang, S.J.; Choi, H.W.; Choi, D.L.; Cho, S.; Rim, H.-K.; Choi, H.-E.; Kim, K.-S.; Huang, M.; Rhim, H.; Lee, K.-T. In vitro cytotoxicity on human ovarian cancer cells by T-type calcium channel blockers. Bioorg. Med. Chem. Lett. 2013, 23, 6656-6662. [CrossRef] [PubMed]

279. Goldner, T.; Hewlett, G.; Ettischer, N.; Ruebsamen-Schaeff, H.; Zimmermann, H.; Lischka, P. The novel anticytomegalovirus compound AIC246 (Letermovir) inhibits human cytomegalovirus replication through a specific antiviral mechanism that involves the viral terminase. J. Virol. 2011, 85, 10884-10893. [CrossRef] [PubMed]

280. Marschall, M.; Stamminger, T.; Urban, A.; Wildum, S.; Ruebsamen-Schaeff, H.; Zimmermann, H.; Lischka, P. In Vitro Evaluation of the Activities of the Novel Anticytomegalovirus Compound AIC246 (Letermovir) against Herpesviruses and Other Human Pathogenic Viruses. Antimicrob. Agents Chemother. 2012, 56, 1135-1137. [CrossRef] [PubMed]

281. Magyar, C.L.; Wall, T.J.; Davies, S.B.; Campbell, M.V.; Barna, H.A.; Smith, S.R.; Savich, C.J.; Mosey, R.A. Triflic anhydride mediated synthesis of 3,4-dihydroquinazolines: A three-component one-pot tandem procedure. Org. Biomol. Chem. 2019, 17, 7995-8000. [CrossRef] [PubMed]

282. Vermeiren, C.; de Hemptinne, I.; Vanhoutte, N.; Tilleux, S.; Maloteaux, J.M.; Hermans, E. Loss of metabotropic glutamate receptor-mediated regulation of glutamate transport in chemically activated astrocytes in a rat model of amyotrophic lateral sclerosis. J. Neurochem. 2006, 96, 719-731. [CrossRef]

283. Benmohamed, R.; Arvanites, A.C.; Kim, J.; Ferrante, R.J.; Silverman, R.B.; Morimoto, R.I.; Kirsch, D.R. Identification of compounds protective against G93A-SOD1 toxicity for the treatment of amyotrophic lateral sclerosis. Amyotroph. Lateral. Scler. 2011, 12, 87-96. [CrossRef]

284. Santoro, A.M.; Lanza, V.; Bellia, F.; Sbardella, D.; Tundo, G.R.; Cannizzo, A.; Grasso, G.; Arizzi, M.; Nicoletti, V.G.; Alcaro, S.; et al. Pyrazolones Activate the Proteasome by Gating Mechanisms and Protect Neuronal Cells from $\beta$-Amyloid Toxicity. ChemMedChem 2020, 15, 302-316. [CrossRef] 